\title{
DIOGO OLIVEIRA
}

A extensão dos poderes de efetivação e a técnica coercitiva na execução pecuniária no CPC/2015

\author{
Dissertação de Mestrado \\ Orientador: Prof. Dr. Walter Piva Rodrigues
}

UNIVERSIDADE DE SÃO PAULO

FACULDADE DE DIREITO

São Paulo - SP

2020 



\section{DIOGO OLIVEIRA}

A extensão dos poderes de efetivação e a técnica coercitiva na execução pecuniária no $\mathrm{CPC} / 2015$

Dissertação apresentada à Banca Examinadora do Programa de Pós-Graduação em Direito, da Faculdade de Direito da Universidade de São Paulo, como exigência parcial para obtenção do título de Mestre em Direito, na área de concentração Direito Processual, sob a orientação do Prof. Dr. Walter Piva Rodrigues.

\section{UNIVERSIDADE DE SÃO PAULO FACULDADE DE DIREITO \\ São Paulo - SP 2020}


Catalogação da Publicação

Serviço de Biblioteca e Documentação

Faculdade de Direito da Universidade de São Paulo

\section{Oliveira, Diogo}

A extensão dos poderes de efetivação e a técnica coercitiva na execução pecuniária no CPC/2015 ; Diogo Oliveira ; orientador Walter Piva Rodrigues -- São Paulo, 2020.

$$
244 \mathrm{f} \text {. }
$$

Dissertação (Mestrado - Programa de Pós-Graduação em Direito Processual) - Faculdade de Direito, Universidade de São Paulo, 2020.

1. Execução. 2. Obrigações pecuniárias. 3. Poderes do juiz. 4. Medidas coercitivas atípicas. I. Rodrigues, Walter Piva, orient. II. Título. 
Nome: OLIVEIRA, Diogo.

Título: A extensão dos poderes de efetivação e a técnica coercitiva na execução pecuniária no CPC/2015.

Dissertação apresentada à Faculdade de Direito da Universidade de São Paulo para obtenção do título de Mestre em Direito, na área de concentração Direito Processual.

Aprovado em:

Banca Examinadora

Prof. Dr.

Instituição

Julgamento

Prof. Dr.

Instituição

Julgamento

Prof. Dr.

Instituição

Julgamento 

Dedico esse trabalho a Lucas Oliveira (in memoriam). 



\section{AGRADECIMENTOS}

Agradeço inicialmente ao Prof. Walter Piva Rodrigues, pela valiosa orientação e contribuições para o meu desenvolvimento acadêmico. Levo o exemplo de um ser humano excepcional, sempre gentil e atencioso.

Aos Profs. José Carlos Baptista Puoli e Heitor Vitor Mendonça Sica, pelos ricos comentários apresentados na banca de qualificação e por todos os ensinamentos durante os créditos do mestrado.

Uma lembrança ao Prof. Rodolfo da Costa Manso Real Amadeo, com minha sincera gratidão por todo o apoio e incentivo para o meu ingresso na academia.

Aos meus pais, Dalva e Leandro, por tudo. Jamais poderei agradecer com palavras pelo apoio em todos os momentos.

À Carolina, meu grande amor, pelo carinho diário e uma vida de parceria, por tudo o que já vivemos e ainda iremos viver.

Aos meus irmãos, Bárbara, Mateus, Vitória e Bruno, pela cumplicidade e pelas alegrias compartilhadas.

Não poderia deixar de mencionar os amigos de Jaboticabal, pelas memórias de infância e pelas grandes histórias.

Aos amigos da PUC-SP, FGV e das Arcadas, companheiros de ontem e hoje, por sempre estarem presentes e pelos divertidos momentos.

Deixo também um agradecimento aos colegas do Mattos Filho, do Cescon Barrieu e do TozziniFreire Advogados, pelo agradável convívio ao longo dos anos e por tudo o que me ensinaram. 



\section{RESUMO}

\section{OLIVEIRA, Diogo. A extensão dos poderes de efetivação e a técnica coercitiva}

na execução pecuniária no CPC/2015. 2020. 244 f. Dissertação (Mestrado em

Direito) — Faculdade de Direito, Universidade de São Paulo, 2020.

O presente trabalho analisou o emprego das medidas coercitivas atípicas na tutela das obrigações pecuniárias, expressamente previstas no artigo 139, inciso IV, do $\mathrm{CPC} / 2015$. Como ponto de partida, foram apresentadas as premissas básicas da teoria geral da execução necessárias à compreensão do tema dos poderes de efetivação na tutela executiva, o conceito de tipicidade e atipicidade dos meios de execução e a mudança de paradigma que autorizou o emprego dos meios coercitivos na execução de obrigações pecuniárias. Após, com a realização de pesquisa de jurisprudência, de forma qualitativa em relação ao Superior Tribunal de Justiça e de forma quantitativa em relação ao Tribunal de Justiça do Estado de São Paulo, foi obtido diagnóstico que permitiu aferir os elementos de legitimação e os elementos de limitação do emprego da técnica coercitiva na execução pecuniária. A partir da análise desses dados, foi realizada investigação sobre os parâmetros de ordem constitucional, infraconstitucional encontrados da legislação processual e outros extraídos do ordenamento jurídico brasileiro e que influenciam o tratamento a ser dado em relação ao emprego das medidas coercitivas atípicas. Por fim, com a sistematização de tudo o quanto foi estudado, o trabalho apresentou um guia prático a ser observado na aplicação das medidas coercitivas atípicas.

Palavras-chave: Execução. Obrigações pecuniárias. Poderes do juiz. Medidas coercitivas atípicas. 



\begin{abstract}
OLIVEIRA, Diogo. The extent of enforcement powers and the coercive technique in money judgements pursuant to Brazilian Civil Procedure Code of 2015. 2020. 244 p. Dissertation (Masters of Law) - Faculdade de Direito, Universidade de São Paulo, 2020.
\end{abstract}

This dissertation analyzed usage of atypical coercive measures in the enforcement of money judgments, which have been expressly established by section 139, item IV, of the Brazilian Civil Procedure Code. Firstly, we have presented the basic premises needed to comprehend judicial powers, the concept of typical and atypical enforcement acts and the paradigm shift that allowed for usage of coercive measures in money judgment. Following, by means of a qualitative survey of Superior Tribunal of Justice case law and by means of a quantitative survey of São Paulo State Court of Appeals case law, we have obtained a diagnosis that allowed us to access which elements entitle and which elements limit usage of the coercive technique in money judgments. Using analysis of this data as a starting point, we have investigated parameters deriving from the Brazilian Federal Constitution, from the civil procedure legislation and others present in the Brazilian legal system that can influence usage of atypical coercive measures. Ultimately, with the systematic organization of all the studied themes, we have proposed a practical guide to be followed in the usage of atypical coercive measures.

Keywords: Enforcement. Money judgement. Judicial powers. Atypical coercive measures. 



\section{LISTA DE ABREVIATURAS}

CPC/1939 - Código de Processo Civil de 1939 (Decreto-Lei n.․1608/1939) CPC/1973 - Código de Processo Civil de 1973 (Lei n.ำ 5.869/1973)

CPC/2015 - Código de Processo Civil de 2015 (Lei n. 13.105/2015) 



\section{SUMÁRIO}

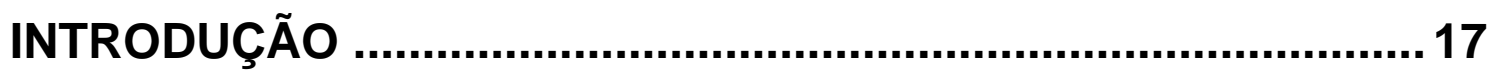

1. DELINEAMENTOS SOBRE O PROCESSO DE EXECUÇÃO POR QUANTIA CERTA E OS PODERES DE EFETIVAÇÃO ................25

1.1. BREVES CONSIDERAÇÕES SOBRE O OBJETO DO ESTUDO CONTEXTUALIZADO PELA TEORIA GERAL DA EXECUÇÃO....................25

1.2. A EXECUÇÃO POR QUANTIA CERTA CONTRA DEVEDOR SOLVENTE

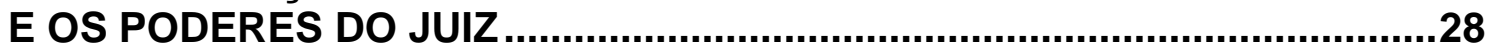

1.3. TIPICIDADE E ATIPICIDADE DOS MEIOS DE EXECUÇÃO NA EXECUÇÃO POR QUANTIA CERTA CONTRA DEVEDOR SOLVENTE ........35 1.4. A MUDANÇA DO PARADIGMA DA EXECUÇÃO INDIRETA - DO CPC/1939 AO CPC/2015..................................................................43

2. A JURISPRUDÊNCIA A RESPEITO DO EMPREGO DA TÉCNICA COERCITIVA NA EXECUÇÃO PECUNIÁRIA ..............55

2.1. A APLICAÇÃO DO ARTIGO 139, INCISO IV, DO CPC/2015, PELO

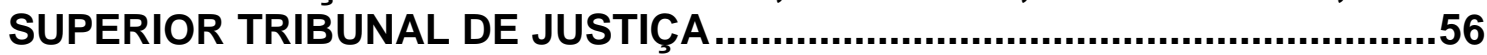

2.1.1. METODOLOGIA DE ANÁLISE DE JULGADOS .................................56

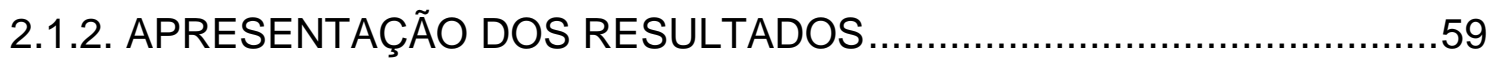

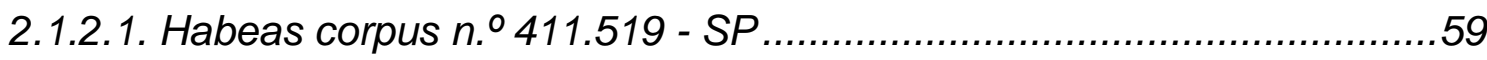

2.1.2.2. Agravo interno no agravo em recurso especial $n .01 .233 .016-S P$......61

2.1.2.3. Recurso em habeas corpus n. 997.876 - SP ...................................62

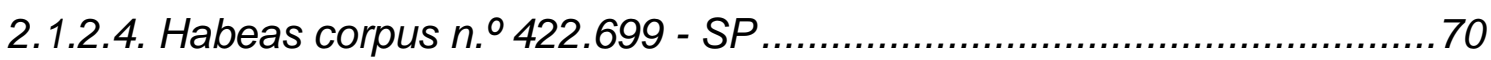

2.1.2.5. Recurso em habeas corpus $n .099 .606$ - SP ....................................71

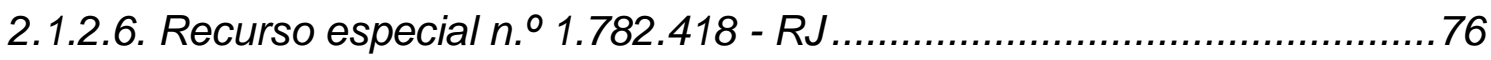

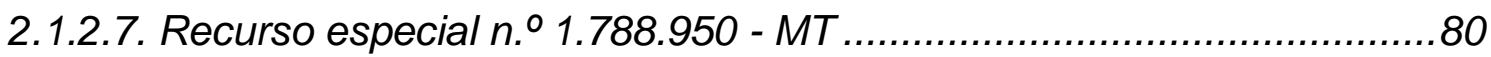

2.1.2.8. Agravo interno no recurso especial n. ${ }^{\circ} 1.785 .726$ - DF.....................81

2.1.3. ANÁLISE DOS RESULTADOS OBTIDOS - PROPOSTA DE INTERPRETAÇÃO DO ESTADO DA ARTE ..............................................

2.2. A JURISPRUDÊNCIA DO TRIBUNAL DE JUSTIÇA DO ESTADO DE SÃO PAULO

2.2.1. A PESQUISA DE GAJARDONI E PEREIRA - JANEIRO A JUNHO DO ANO DE 2017 .84

2.2.2. A PESQUISA DE MEDEIROS NETO E REINAS - JUNHO A AGOSTO DO ANO DE 2018

2.2.3. ATUALIZAÇÃO DA PESQUISA DE GAJARDONI E PEREIRA E MEDEIROS NETO E REINAS - JUNHO A AGOSTO DO ANO DE 2019 ........89

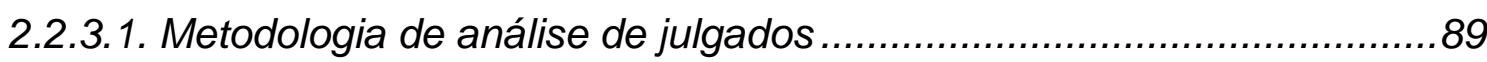

2.2.3.2. Apresentação dos resultados...................................................... 91

2.2.3.3. Análise dos casos em que houve deferimento da medida executiva atípica pleiteada. 
2.3. O DIAGNÓSTICO OFERECIDO PELO LEVANTAMENTO DA JURISPRUDÊNCIA DO SUPERIOR TRIBUNAL DE JUSTIÇA E DO TRIBUNAL DE JUSTIÇA DO ESTADO DE SÃO PAULO ............................................104 3. PARÂMETROS PARA EXERCÍCIO DOS PODERES DE EFETIVAÇÃO NA EXECUÇÃO PECUNIÁRIA............................107

3.1. O PROCESSO CIVIL CONSTITUCIONAL E AS GARANTIAS PROCESSUAIS DO CIDADÃO EM JUÍZO - PONDERAÇÕES SOBRE O EMPREGO DA TÉCNICA COERCITIVA. 107

3.2. PARÂMETROS DE ORDEM CONSTITUCIONAL 117

3.2.1. ACESSO À JUSTIÇA E PRINCÍPIO DA EFETIVIDADE .....................118

3.2.2. PRINCÍPIOS DA PROPORCIONALIDADE E DA RAZOABILIDADE ....126

3.2.3. PRINCÍPIO DA DIGNIDADE DA PESSOA HUMANA …......................135

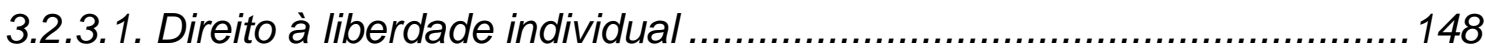

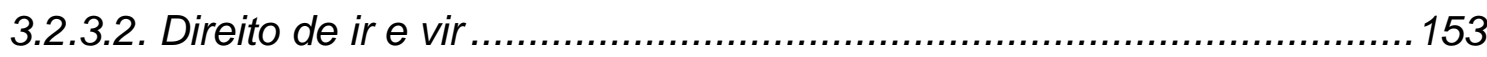

3.2.4. GARANTIA DO CONTRADITÓRIO E DA AMPLA DEFESA .................158

3.2.5. DEVER DE MOTIVAÇÃO DAS DECISÕES JUDICIAIS .......................162

3.3. PARÂMETROS DA LEGISLAÇÃO PROCESSUAL ...............................164

3.3.1. PRINCÍPIO DA MENOR ONEROSIDADE AO DEVEDOR ..................164

3.3.2. PRINCÍPIO DA PATRIMONIALIDADE (REALIDADE) ........................167

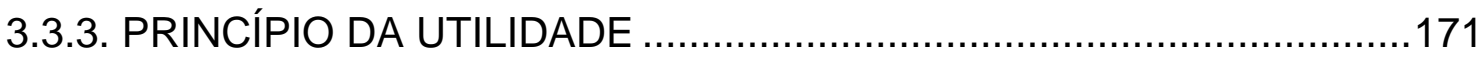

3.4. DEMAIS PARÂMETROS EXTRAÍDOS DO ORDENAMENTO JURÍDICO

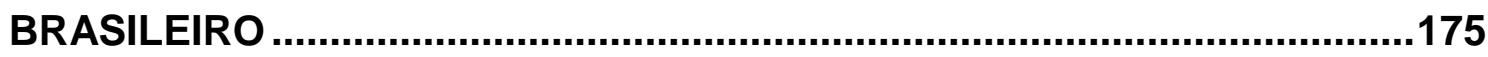

3.4.1. A SUPERAÇÃO DO DOGMA DA INTERFERÊNCIA NA VONTADE ...175

3.4.2. VEDAÇÃO AO CARÁTER SANCIONATÓRIO ...................................178

3.4.3. NECESSIDADE DE ESGOTAMENTO DOS MEIOS TÍPICOS SUBSIDIARIEDADE DOS MEIOS ATÍPICOS............................................185

3.4.4. O REQUERIMENTO EXECUTIVO E O ATO DE OFÍCIO....................193

3.4.5. DA NECESSIDADE DE CORRELAÇÃO ENTRE A MEDIDA A SER APLICADA E O DIREITO MATERIAL PERSEGUIDO …............................196

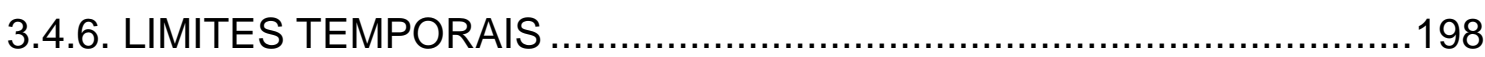

3.5. COMENTÁRIOS SOBRE A CONSTITUCIONALIDADE DO ARTIGO 139,

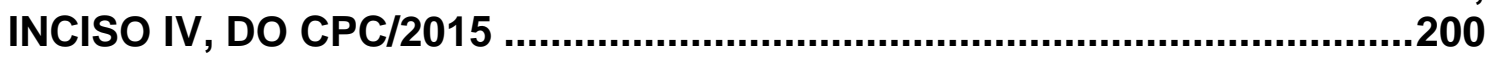

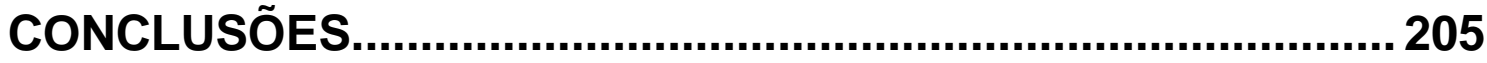

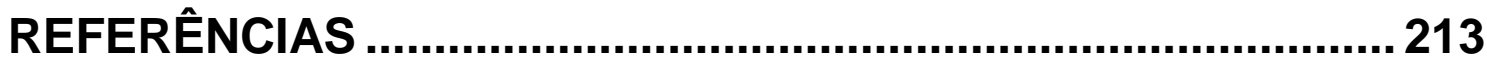

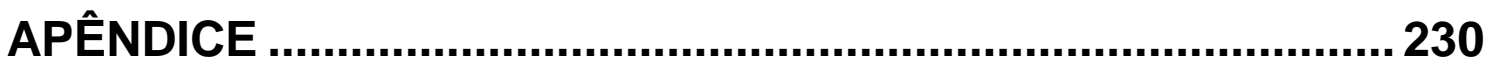




\section{INTRODUÇÃO}

O objeto do estudo ora proposto é a análise da utilização de medidas indutivas, coercitivas ou mandamentais não previstas expressamente em lei para compelir devedores ao cumprimento de ordens judiciais que tenham por objeto prestação de natureza pecuniária.

Em termos técnicos, é um estudo que tem por base verificar a extensão e os limites dos poderes de efetivação do juiz no emprego da técnica coercitiva atípica, de execução indireta, na tutela executiva de natureza pecuniária.

Para o alcance das finalidades propostas, optou-se por limitar o escopo do trabalho às ações que têm por objeto prestação pecuniária de natureza, por assim dizer, puramente civil, como, por exemplo, as ações que visam à satisfação do título executivo judicial ou do título executivo extrajudicial, todas, primordialmente, decorrentes de relações de direito privado.

Assim, o presente estudo tem enfoque nos procedimentos de cumprimento de sentença, definitivo ou provisório, também na ação monitória, e na execução por quantia certa de título executivo judicial ou extrajudicial, ou seja, aqueles relacionados nos artigos 515 e 784 do CPC/2015. Com isso, os poderes de efetivação que são objeto da presente análise poderão ser verificados, na prática jurídica, por exemplo, na execução de cheque, duplicata, cédula de crédito bancário, na execução de título executivo judicial, como a sentença arbitral, no cumprimento da sentença condenatória ao pagamento de indenização por infração contratual, ao pagamento na cobrança de um mútuo, e diversos outros.

Não serão foco desse trabalho, em razão da existência de regramentos específicos para essas hipóteses, modalidades de execução tais como a decorrente de reclamação trabalhista, do crédito de natureza alimentar em geral, a execução fiscal, a execução movida contra a administração pública ou que visem à satisfação de créditos de natureza administrativa. Ou seja, todos aqueles que fogem ao tratamento das relações privadas ou que possuem regramento específico decorrente de tutela diferenciada pelo Estado.

A partir do confronto entre a necessidade de um processo justo e eficaz e que, ao mesmo tempo, assegure proteção dos direitos e garantias fundamentais, com respeito aos princípios constitucionais e infraconstitucionais, serão verificados a extensão e os limites dos poderes de efetivação do juiz no emprego da técnica 
coercitiva na tutela executiva de natureza pecuniária no CPC/2015, com o que se pretende chegar, ao final, a uma sistematização que permita estabelecer as balizas para a utilização prática dessas medidas.

De modo geral, o emprego das técnicas coercitivas resta previsto no artigo 139, inciso IV, do $\mathrm{CPC} / 2015$, que, ao tratar dos poderes, deveres e da responsabilidade do juiz, estabeleceu como uma de suas atribuições "determinar todas as medidas indutivas, coercitivas, mandamentais ou sub-rogatórias necessárias para assegurar o cumprimento de ordem judicial, inclusive nas ações que tenham por objeto prestação pecuniária"1.

A preocupação desse trabalho decorre da constatação de que a lei ordinária não estabeleceu nenhuma forma de ressalva ao disciplinar esse tema, cabendo então ao intérprete buscar os seus limites e restrições - e até questionar a sua constitucionalidade.

Adicionalmente, no contexto da pesquisa conduzida para a elaboração do presente trabalho, verificou-se que os tribunais brasileiros se mostram altamente reticentes quanto à aplicação das medidas coercitivas, apesar de tímida evolução observada em tempos mais recentes, principalmente na jurisprudência do Superior Tribunal de Justiça, de modo que, até para evitar que a inovação legislativa se torne letra morta, esse trabalho de investigação se propõe a sistematizar as conclusões alcançadas e sugerir um guia prático de como as medidas coercitivas atípicas podem ser aplicadas.

Serão conceitos fundamentais para o desenvolvimento desse trabalho a instrumentalidade do processo e a garantia constitucional de acesso à justiça, os quais, respectivamente, tratam da ideia de um processo a serviço da realização do direito material e de pacificação social² ${ }^{2}$ Além disso, há de se levar em conta o dever do Estado de solucionar os conflitos de maneira rápida e efetiva, mediante a aplicação do direito objetivo, abstratamente concebido, ao caso concreto ${ }^{3}$.

A onda reformista na legislação processual brasileira, iniciada na década de 1990 e que culminou na elaboração do CPC/2015, teve como elemento norteador

\footnotetext{
1 BRASIL. Lei n. 13.105, de 16 de março de 2015. Código de Processo Civil, 2015. Disponível em: <http://www.planalto.gov.br/ccivil_03/_ato2015-2018/2015/lei//13105.htm>. Acesso em: 26 jun. 2018.

${ }^{2}$ CINTRA, Antônio Carlos de Araujo; GRINOVER, Ada Pellegrini; DINAMARCO, Cândido Rangel. Teoria geral do processo. 24⿳亠丷厂 ed. São Paulo: Malheiros, 2008. p. 46.

${ }^{3}$ FUX, Luiz. Curso de direito processual civil. Rio de Janeiro: Forense, 2004. p. 41.
} 
a busca pela efetividade do processo. Isto é, assegurar a realização do direito material por meio do processo civil.

A apresentação do anteprojeto do novo código de processo civil, ao detalhar as suas inspirações, informa que se buscou criar diploma apto a "atender aos anseios dos cidadãos no sentido de garantir um novo Código de Processo Civil que privilegie a simplicidade da linguagem e da ação processual, a celeridade do processo e a efetividade do resultado da ação"4.

A fim de concretizar esse ideal de efetividade, ao juiz cabe ser figura viva no processo, pois, conforme Santos, consideramos que "na verdade, ao juiz inerte, ao juiz passivo, de outros tempos, se substituiu o juiz ativo, [...], um juiz que é sujeito predominante da relação processual e como tal desenvolve atividades amplas e variadas" 5 . Contudo, como disse Dinamarco, "se de um lado no Estado moderno não mais se tolera o juiz passivo e espectador, de outro, sua participação ativa encontra limites ditados pelo mesmo sistema de legalidade"6.

Isso quer dizer que devem existir limites à atuação do juiz. Nesse ponto, e porque é esse o objeto de análise desse trabalho, partindo da premissa de que o emprego das medidas indutivas, coercitivas ou mandamentais para assegurar 0 cumprimento de ordens judiciais que tenham por objeto prestação de natureza pecuniária é admissível, porque expressamente previsto pelo legislador no artigo 139, inciso IV, do CPC/2015, se buscará justamente analisar os limites impostos pelo ordenamento jurídico para a sua aplicação.

Para tanto, visto que as medidas de coerção, em sua maioria, se valem da restrição de direitos para compelir determinado indivíduo a dar cumprimento às decisões judiciais que lhe são direcionadas, será necessário analisar o alcance da técnica de execução indireta bem como o papel do juiz na relação processual executiva, passando-se pela noção moderna do processo cooperativo e constitucional, razão pela qual também será necessário investigar se o emprego das medidas coercitivas não importariam em violação à Constituição Federal,

\footnotetext{
4 COMISSÃO DE JURISTAS RESPONSÁVEL PELA ELABORAÇÃO DO ANTEPROJETO DO NOVO CÓDIGO DE PROCESSO CIVIL. Anteprojeto do novo código de processo civil. Brasília: Senado Federal, Subsecretaria de Edições Técnicas, 2010. Disponível em: <http://www2.senado.leg.br/bdsf/handle/id/496296>. Acesso em: 02 out. 2019. p. 06.

5 SANTOS, Moacyr Amaral. Primeiras linhas de direito processual civil. São Paulo: Saraiva, 1995. p. 326.

${ }^{6}$ DINAMARCO, Cândido Rangel. A instrumentalidade do processo. 10ª ed. São Paulo: Malheiros, 2002. p. 244.
} 
especialmente no que diz respeito ao princípio da proporcionalidade, à dignidade humana e às garantias individuais.

Aprofundando a análise dos poderes de efetivação, se buscará dar conceito e critérios de aplicação aos comandos colocados à disposição do juiz para assegurar o cumprimento das ordens judiciais. E, por meio do estudo das regras constitucionais e infraconstitucionais de proteção aos direitos fundamentais, será verificada eventual necessidade de limitação dos poderes de efetivação do juiz no que se refere às medidas coercitivas colocadas à sua disposição.

A hermenêutica jurídica será empregada para verificar se a tais comandos judiciais, analisados adequadamente de acordo com o espírito da lei e de forma sistemática, é dada interpretação que assegure a sua legalidade e possibilidade de aplicação prática como forma de aumentar a efetividade do processo de execução.

A análise do tema objeto dessa proposta de estudo é necessária por diversos motivos. A regra genérica de ampliação dos poderes do juiz na prestação da tutela executiva, sem qualquer limitação aparente, pode criar situações de injustiça e de ofensa aos direitos individuais, afastando o processo da sua finalidade de realização do direito material e de pacificação social.

A problemática é recente e está incluída no fértil campo de estudos que surgiu com o CPC/2015, razão pela qual aqui, modestamente, se pretende somar força ao corpo de estudiosos expressando opinião sobre o tema, na esperança de vê-lo adequadamente aplicado pelos tribunais brasileiros.

Ademais, é de se reconhecer que a efetividade do processo certamente é elemento importante para o ordenamento jurídico brasileiro, contudo, tal ideal não se deve buscar a qualquer custo, em ofensa aos direitos fundamentais. Assim sendo, é necessário investigar os limites dos poderes de efetivação a fim de mantêlos em linha com a Constituição Federal e com o sistema processual.

No ponto central dessa discussão se pode verificar a preocupação com o direito de satisfação do crédito, agravada, pelo que se pode depreender das próprias matérias acima referenciadas, por um sentimento coletivo de insatisfação, de um certo fracasso do poder judiciário em dar eficácia ao cumprimento das obrigações de pagar quantia certa. É comum no cotidiano jurídico brasileiro a figura do devedor contumaz, que deve e não paga não porque não pode, mas porque não quer, tendo se profissionalizado em ocultar o seu patrimônio e se esquivar dos seus credores. 
De outro lado, também são justificadas as preocupações daqueles que veem com cautela a ampliação dos poderes do juiz, que possibilitariam a aplicação de toda sorte de medidas coercitivas para a satisfação de direitos meramente patrimoniais, o que, como entendem, poderia ofender a direitos, como o de ir e vir e colocar o devedor em situação não condizente com a dignidade humana.

A corroborar a relevância do tema, vê-se que é farta a produção intelectual sobre esse assunto, tendo sido publicados diversos artigos científicos, artigos de opinião e livros desde a promulgação do CPC/2015. Porém, por ser assunto novo, faltam estudos de fôlego, com o aprofundamento que as particularidades do problema exigem, sobre justamente qual seria a extensão dos poderes de efetivação e da técnica coercitiva na execução pecuniária.

Não apenas a farta produção acadêmica sobre o assunto é um indicativo da relevância do tema. Ao oferecer sua contribuição à interpretação do artigo 139, inciso IV, do CPC/2015, Talamini destaca a grande diversidade de entendimentos encontrados na literatura a respeito da sua aplicação na tutela executiva referente às obrigações pecuniárias. Segundo o autor, na doutrina, existem os que negam peremptoriamente a incidência de medidas atípicas; os que, ainda que sem estabelecer uma negativa absoluta, rejeitam haver elementos que autorizem atribuir ao artigo 139, inciso IV, um papel que possa interferir significativamente sobre o procedimento tipificado; outros que defendem a incidência do artigo 139, inciso IV, de forma limitada, destinando-a a casos em que haja indícios de ocultação ou blindagem patrimonial, obstrução da justiça pelo devedor ou violação a deveres processuais de colaboração com o juízo executivo; ou afirmam um caráter excepcional ou subsidiário; há também os que rejeitam a aplicação contra o Poder Público; e, por fim, há aqueles que estabelecem ressalvas gerais de respeito à proporcionalidade e de correlação entre a medida executiva atípica e a decisão que se deve cumprir ${ }^{7}$. Vale dizer que o próprio Talamini propõe interpretação diversa dessas, afirmando que o poder geral para medidas atípicas teria cabimento apenas

\footnotetext{
7 TALAMINI, Eduardo. Poder geral de adoção de medidas executivas e sua incidência nas diferentes modalidades de execução. In: TALAMINI, Eduardo; MINAMI, Marcos Youji (coords.). Medidas executivas atípicas. Salvador: JusPodivm, 2018. p. 46-47.
} 
diante de ordem do juiz, assim entendido como o pronunciamento com conteúdo mandamental ${ }^{8}$.

A preocupação em sistematizar a atuação dos poderes de efetivação, inclusive, mostra-se como uma inquietação a nível global, pois, conforme Greco, em todos os ordenamentos que autorizaram o emprego da técnica coercitiva indireta, surgiram preocupações com os limites dessas medidas na invasão às esferas de liberdade pessoal e patrimonial do devedor ${ }^{9}$.

Assim, entendemos que, com a presente contribuição à comunidade acadêmica, poderemos cooperar com a delimitação das balizas para aplicação das medidas indutivas, coercitivas, mandamentais para assegurar o cumprimento de ordem judicial nas ações que tenham por objeto prestação pecuniária, protegendo os direitos fundamentais do devedor e, ao mesmo tempo, assegurando a efetividade da tutela executiva.

O presente trabalho será desenvolvido a partir do método indutivo, com a conceituação e delimitação das premissas menores que se entende sejam pertinentes para a compreensão do todo para, ao final, se extrair da presente compilação os elementos necessários para a apresentação de resposta aos problemas de pesquisa ora apresentados.

A percepção das premissas menores se pretende alcançar por meio da revisão da literatura produzida sobre o tema e análise da jurisprudência dos tribunais brasileiros.

Como a questão posta em análise é recente na doutrina brasileira, com o objetivo de se assegurar a plena compreensão do objeto de estudo, serão empregados os métodos de procedimento comparativo e sistêmico. Isso porque, ainda que o tratamento dispensado aos poderes de efetivação na execução da obrigação pecuniária seja particular ao CPC/2015, o fenômeno encontra semelhanças com o tratamento dado aos poderes de efetivação de um modo geral, na legislação atual e em diplomas do passado.

Isso posto, a presente pesquisa se apresenta em um trabalho composto por três capítulos.

\footnotetext{
${ }^{8}$ TALAMINI, Eduardo. Poder geral de adoção de medidas executivas e sua incidência nas diferentes modalidades de execução. In: TALAMINI, Eduardo; MINAMI, Marcos Youji (coords.). Medidas executivas atípicas. Salvador: JusPodivm, 2018. p. 56.

9 GRECO, Leonardo. Coações indiretas na execução pecuniária. Revista da EMERJ, Rio de Janeiro, v. 20, n. 1, p. 109-134, jan./abr. 2018. p. 112
} 
O primeiro capítulo buscará estabelecer premissas básicas para a compreensão do tema dos poderes de efetivação na tutela executiva. Para tanto, serão abordados conceitos da teoria geral da execução, com análise dos fundamentos do processo de execução, dos títulos executivos judiciais e extrajudiciais e sua autoridade para embasar a atividade jurisdicional e a decisão executiva no processo de execução. No mais, esse capítulo introduzirá a temática dos poderes de efetivação na execução, tecendo breves comentários sobre a tipicidade e atipicidade dos meios executivos, e, por fim, sobre a mudança de paradigma verificada na transição do CPC/1973 para o CPC/2015 a respeito da execução indireta nas ações que tenham por objeto prestação pecuniária.

O segundo capítulo apresenta pesquisa qualitativa quanto à jurisprudência do Superior Tribunal de Justiça e quantitativa quanto à jurisprudência do Tribunal de Justiça do Estado de São Paulo, com o que se pretende obter diagnóstico das causas que permitem ou vedam a aplicação da técnica coercitiva, bem como importantes parâmetros e requisitos já depurados pela experiência judicial.

Na sequência, estabelecidas as premissas básicas para a compreensão dos poderes de efetivação na tutela executiva e de posse do diagnóstico oferecido pelo levantamento jurisprudencial, o terceiro capítulo discorrerá sobre parâmetros sistêmicos que devem nortear o emprego dos poderes de efetivação e da técnica coercitiva de execução indireta. Busca-se também apresentar uma proposta de solução para a colisão de princípios e o conflito de regras na tutela executiva e, assim, apresentar as diretrizes fundamentais à definição da extensão e limites dos poderes de efetivação e da técnica coercitiva na tutela executiva, de modo a evidenciar o regime jurídico aplicado ao tema e sistematizar todos os conceitos fundamentais à proposta dessa pesquisa.

A metodologia específica a ser empregada nos três primeiros capítulos será baseada no método crítico-descritivo, para, essencialmente, se estabelecer as premissas necessárias à compreensão da extensão dos poderes de efetivação.

A conclusão buscará sistematizar o exercício da técnica coercitiva na execução pecuniária no CPC/2015, apresentando critérios práticos, requisitos e o procedimento a serem observados pelo juiz.

O método específico a ser utilizado no desenvolvimento do quinto e último capítulo é o crítico-prescritivo, de modo a traduzir para o plano prático as conclusões teóricas dessa pesquisa ou já consolidadas na doutrina. 
Essa análise será feita de forma sistemática, considerando o regramento constitucional e infraconstitucional, para, com isso, estabelecer as balizas para aplicação da técnica coercitiva na execução pecuniária.

Em razão da mudança de paradigma sobre os poderes de efetivação no que se refere à execução da obrigação pecuniária no CPC/2015, se entendeu por desnecessário o aprofundamento meramente fático sobre o desenvolvimento histórico do tema no direito brasileiro, o que não significa dizer, contudo, que digressões necessárias à compreensão da mudança de paradigma não poderão ser empregadas. Do contrário, ao longo do presente trabalho, sempre que se fizer necessário, serão analisadas as mudanças pontuais na lei e na interpretação a ela conferida nos períodos pertinentes.

No mais, dadas as particularidades do ordenamento brasileiro quanto ao tratamento da ação de execução, em qualquer modalidade que seja, não nos parece justificável, em razão dos limites propostos para esse trabalho, o cotejo com o tratamento dado à temática em ordenamentos estrangeiros, notadamente porque tal levantamento já foi realizado, com distinta competência, por outros pesquisadores, em trabalhos de relevo que têm o mesmo tema central que a presente análise ${ }^{10}$.

Feitas essas considerações, as questões de caráter geral que se pretende responder com essa pesquisa são as seguintes: (i) Quais são os critérios a serem observados pelo juiz na utilização da técnica coercitiva na execução pecuniária considerando as disposições do CPC/2015? e (ii) como sopesar e dar aplicabilidade prática à técnica coercitiva na execução pecuniária verificada a colisão entre a busca pela efetividade e realização do direito material por meio da tutela executiva e os direitos fundamentais, princípios constitucionais, infraconstitucionais e demais elementos existentes no ordenamento brasileiro que limitam a atuação do juiz e conferem proteção ao devedor?

10 Ver GUERRA, Marcelo Lima. Execução indireta. São Paulo: Revista dos Tribunais, 1998; OLIVEIRA NETO, Olavo de. O poder geral de coerção. São Paulo: Thomsom Reuters Brasil, 2019. E, também, BORGES, Marcus Vinícius Motter. Medidas coercitivas atípicas nas execuções pecuniárias: parâmetros para a aplicação do art. 139, IV do CPC/15. São Paulo: Thomsom Reuters Brasil, 2019. 


\section{CONCLUSÕES}

A execução é uma das funções jurisdicionais do Estado e, por meio dela, se realizam os atos necessários à efetivação do direito previamente reconhecido, por sentença ou em título executivo, com a transformação, no mundo real, daquilo que é, naquilo que deve ser. Em outras palavras, a execução visa a realizar o direito que não foi espontaneamente satisfeito por aquele que estava obrigado a determinada prestação.

No Brasil, a execução se realiza por meio de um processo de execução, conduzido, portanto, pelo Poder Judiciário, no qual o executado, porque não satisfez espontaneamente a sua obrigação, fica em um estado de sujeição, devendo suportar os atos que o juiz determinar para a realização do direito de titularidade do exequente.

O objeto do nosso estudo está centrado na realização do direito à uma prestação pecuniária, particularmente aquelas de natureza cível. Essas são realizadas por meio da execução por quantia certa ou por meio do cumprimento da sentença que reconhece a exigibilidade de obrigação de pagar quantia certa.

Para essa finalidade de realização da obrigação pecuniária, o juiz se valerá dos atos de execução, que podem ser sub-rogatórios ou coercitivos.

Com os meios sub-rogatórios, o Estado se substitui à vontade do executado e expropria-Ihe o patrimônio para a satisfação da execução, hipótese na qual se diz ter lugar a execução direta. A expropriação consiste em adjudicação, alienação ou apropriação de frutos e rendimentos.

Com os meios coercitivos, o Estado pode impor uma piora ou melhora na situação fática do executado com o objetivo de influenciar a sua vontade para que diretamente satisfaça a obrigação ou fomente as condições para que ela seja satisfeita, hipótese na qual se diz ter lugar a execução indireta. São exemplos de medidas coercitivas a multa, a prisão civil, o desconto no valor devido a título de honorários advocatícios como sanção premial, o cadastro nas listas de maus pagadores, a apreensão de passaporte e muitos outros.

Diz-se que são típicas as medidas que estão expressamente previstas em lei e atípicas as medidas que derivam de uma cláusula geral, sem previsão legal específica. 
Assim, o objetivo específico do nosso trabalho foi a análise da aplicabilidade das medidas coercitivas atípicas, ou seja, daquelas que se prestam a influenciar a vontade do devedor e que não estão expressamente previstas em lei.

Apenas com a nova legislação processual - particularmente na redação do artigo 139, inciso IV, do CPC/2015, que autoriza o juiz a determinar todas as medidas indutivas, coercitivas, mandamentais ou sub-rogatórias necessárias para assegurar o cumprimento de ordem judicial, inclusive nas ações que tenham por objeto prestação pecuniária - é que se sedimentou a possibilidade de emprego da técnica coercitiva para a efetivação de obrigações dessa natureza.

Esse é o ápice de um movimento histórico pendular, observando um primeiro extremo nas Ordenações Filipinas, que admitiam a prisão do devedor que dolosamente retardasse a satisfação da execução, de qualquer natureza, passando pelo CPC/1939, que limitava as medidas coercitivas à tipificação expressa de aplicação de multa nas obrigações infungíveis, limitando a prisão civil típica aos casos de dívida alimentícia, e indo adiante com o CPC/1973, que admitia a multa pecuniária para qualquer obrigação de fazer ou não fazer, mantida a prisão civil para o devedor de alimentos. Uma nova onda progressista, iniciada com a promulgação do Código de Defesa do Consumidor em 1990 e avançada com as reformas do CPC/1973 a partir de 1994, acabou por consagrar a primazia da tutela específica e a possibilidade de emprego de medidas para assegurar o resultado prático equivalente nas execuções de fazer, não fazer e dar, fungíveis ou infungíveis, sem expressa previsão de quais seriam essas medidas, ampliando o grau de flexibilidade dos poderes do juiz. Prosseguindo, a segunda onda de reformas, iniciada no ano de 2002, passou a permitir o emprego de medida coercitiva típica de aplicação de multa na tutela do cumprimento de sentença que reconhece a exigibilidade de obrigação de pagar quantia certa, em clara inovação no tratamento da tutela da obrigação pecuniária.

Como o legislador não detalhou o procedimento de emprego das medidas coercitivas atípicas na execução, o que, por um lado, tem o mérito de dar ao juiz a flexibilidade necessária para dirigir o processo como for mais adequado no caso concreto, por outro, carrega o vício da possibilidade de arbitrariedades e excessos judiciais, vimos a necessidade de buscar no ordenamento brasileiros os limites e a extensão dos poderes de efetivação do juiz, observando o ideal de efetividade tido 
como norte para as alterações legislativas, mas sem esquecer a proteção dos direitos e garantias fundamentais.

Nesse contexto, a pesquisa da jurisprudência dos tribunais brasileiros, realizada de forma qualitativa perante o Superior Tribunal de Justiça e de forma quantitativa, com levantamento jurimétrico, perante o Tribunal de Justiça do Estado de São Paulo, nos revelou que ainda há grande reticência na aplicação das medidas coercitivas atípicas.

Particularmente, a pesquisa realizada perante o Superior Tribunal de Justiça nos mostrou que a corte superior reconhece o avanço legislativo, admite o emprego das medidas coercitivas atípicas na execução de obrigação pecuniária com a ressalva de que devem ser prestigiadas interpretações que sejam constitucionalmente possíveis e oferece um modelo de aplicação funcional, mas insuficiente. São contribuições importantes a definição de que a medida de apreensão de passaporte não deve ser automaticamente considerada vedada, que a medida de suspensão da carteira nacional de habilitação não causa ofensa imediata ao direito de ir e vir e que, de um modo geral, as medidas executivas atípicas não devem ser confundidas com a sanção civil de natureza material. De acordo com os julgados analisados, para o Superior Tribunal de Justiça, é necessário que se observe na aplicação das medidas coercitivas atípicas na execução pecuniária juízo de proporcionalidade segundo o binômio adequação e necessidade, a ser realizado caso a caso e de acordo com a hipótese concreta; que seja observado o contraditório prévio, sendo que a invocação de defesa baseada no princípio da menor onerosidade somente será acolhida para afastar a aplicação de medidas executivas atípicas caso o devedor indique meio menos gravoso e igualmente eficaz para a satisfação da dívida; que seja devidamente fundamentada a necessidade de aplicação da medida executiva atípica e que sejam demonstrados indícios mínimos que sugiram que o devedor possui bens aptos a satisfazer a dívida.

A atualização da pesquisa de Fernando da Fonseca Gajardoni em coautoria com Augusto Martins Pereira e Elias Marques de Medeiros Neto em coautoria com Caroline Pastri Pinto Reinas, nos mostra que o Tribunal de Justiça do Estado de São Paulo tem a tendência de rejeitar os pedidos de aplicação das medidas coercitivas atípicas, haja vista que, as três iterações do levantamento apontam para uma taxa média de deferimento das medidas executivas atípicas inferior a dez por 
cento do total de casos. No mais, a pesquisa perante o Tribunal de Justiça do Estado de São Paulo oferece como diagnóstico que o princípio da efetividade é o grande elemento potencializador da aplicação das medias coercitivas atípicas e que o elemento limitador é, principalmente, a proteção aos direitos e garantias individuais, notadamente a dignidade da pessoa humana e, no particular das medidas restritivas de locomoção, o direito de ir e vir. Também se mostraram relevantes causas de indeferimento das medidas coercitivas atípicas a possibilidade de inocuidade da medida, o princípio da patrimonialidade da execução, o princípio da menor onerosidade, a subsidiariedade dos meios atípicos em relação aos típicos, a vedação ao caráter punitivo, a necessidade de prova de sinais externos de riqueza ou indício de ocultação de bens, o respeito ao contraditório e a necessidade de fundamentação das decisões judiciais.

Com base nesses elementos, a investigação analisou que o estudo do tema pela perspectiva do processo civil constitucional e a existência de garantias processuais do cidadão em juízo são o verdadeiro norte para a aplicação das medidas coercitivas atípicas.

Pontuou-se que a execução não é instrumento de exercício de vingança privada e que os direitos fundamentais impõem certas barreiras ao processo civil, devendo existir limites para a atuação dos poderes do juiz.

Considerou-se, também, que a execução pecuniária pela técnica sub-rogatória é capaz de satisfazer aos interesses do exequente e que a legislação processual já oferece algumas soluções para lidar com o devedor de má-fé e a fraude material, mas que algumas situações permaneciam desprotegidas, notadamente com os sofisticados esquemas de ocultação patrimonial, e que, para essas situações, faz-se necessária a existência de medidas capazes de dobrar a vontade do devedor, constrangendo-o a revelar a existência de patrimônio penhorável ou a satisfazer a obrigação diretamente.

A simples existência da crise de efetividade torna necessário que se redobrem os esforços para assegurar a plena validade da garantia de acesso à justiça e o próprio princípio da efetividade, especialmente porque também é um direito fundamental o direito a uma tutela efetiva.

Desse modo, se os meios coercitivos podem ser eficientes e capazes de entregar ao credor o que lhe é devido, com maior celeridade, é legítimo que os juízes os empreguem na execução por quantia certa. 
O emprego da medida coercitiva atípica será possível, na espécie, se passar pelo teste da proporcionalidade, pelas suas três máximas, da adequação, necessidade e proporcionalidade em sentido estrito. A medida será adequada se ao menos for capaz de fomentar a realização do direito à prestação pecuniária, isso é, deverá deixar o credor mais perto de receber os valores que persegue por meio da execução, pelo que será possível o emprego das medidas coercitivas atípicas para forçar o devedor a cumprir a obrigação diretamente, a indicar bens penhoráveis ou a cumprir deveres processuais laterais, como colaborar na avaliação e alienação dos bens penhorados. A medida será necessária caso, sem o seu emprego, o direito não puder ser realizado de forma igualmente eficiente e menos gravosa. A medida observará a proporcionalidade em sentido estrito se a sua aplicação oferecer vantagens superiores ao prejuízo sistêmico que for capaz de causar, particularmente pelo confronto e sopesamento entre a efetividade e a restrição dos direitos fundamentais.

A medida coercitiva atípica a ser empregada também deverá ser razoável, pela perspectiva da equidade, que exige a sua harmonização com o caso concreto, pela perspectiva da congruência, que exige seja observado o espírito da lei e a intenção do legislador, modulados pelo momento histórico de edição da lei e, por fim, pela perspectiva da equivalência, entre a medida adotada e os critérios que a dimensionam.

Paralelamente, além de razoável e proporcional, o emprego da medida deve observar a proibição ao excesso, pelo que não será aceita nenhuma medida coercitiva atípica que restrinja por completo um direito fundamental.

Isso está em linha com as consequências impostas pelo respeito ao princípio da dignidade da pessoa humana, que, apesar de não ser absoluto, impõe a existência de um núcleo mínimo de dignidade nos direitos fundamentais dela derivados ou por ela influenciados que jamais poderá ser restringido. Ou seja, o juiz, ao aplicar as medidas coercitivas atípicas, deverá cuidar para que esse mínimo de dignidade seja garantido; senão a medida será contrária à Constituição Federal e deverá ser cassada. Além disso, será necessário que se evite superestimar o princípio da dignidade humana e verificar se, na prática, de fato ocorre a sua violação, pois é certo que nem todas as medidas executivas, restritivas de direito ou não, são violadoras da dignidade humana. 
Nesse contexto, aliás, o aparte que abrimos para tratar da compatibilidade da dignidade humana com a restrição de direitos à liberdade individual e de ir e vir, que recebem grande destaque doutrinário no estudo das medidas coercitivas, nos levou a concluir que, em princípio, a Constituição Federal não proíbe o emprego da prisão civil para compelir o indivíduo a cumprir uma ordem judicial e também não proíbe a apreensão de passaporte ou da carteira de motorista. Essas medidas, então, poderão ser aplicadas caso a caso, observado, além da proporcionalidade e razoabilidade, o ônus de argumentação e fundamentação que a gravidade dessas medidas exige.

Como a execução se realiza em um processo judicial, além disso, deverão ser observadas as garantias processuais do contraditório e da ampla defesa e a de fundamentação das decisões judiciais.

Não há dúvida de que o contraditório deve ser observado em todo e qualquer processo, até pela existência de expressa determinação legal nesse sentido. De qualquer forma, as particularidades do processo de execução e o risco de o devedor se furtar às determinações judiciais, autorizam que o contraditório seja diferido.

Considerando que o emprego da técnica coercitiva tem a capacidade de fazer restringir direitos e garantias fundamentais, a fundamentação da decisão deverá ser particularmente cuidadosa, haja vista que apenas pela fundamentação se confere legitimidade à decisão judicial e se viabiliza o controle dos excessos, sendo a motivação necessária para aferir se o emprego da técnica coercitiva foi correto; daí a necessidade de que a demonstração do convencimento do juiz passe pela satisfação dos requisitos de aplicabilidade das medidas coercitivas atípicas.

Enquanto incidente em processo de execução, as medidas coercitivas atípicas empregadas no âmbito da tutela da obrigação pecuniária, deverão observar, ainda, os princípios da menor onerosidade, da patrimonialidade e da utilidade.

O princípio da menor onerosidade ao devedor surge como expressão do princípio da proporcionalidade pela máxima da necessidade, com o que se deve impor ao executado apenas o estritamente necessário para assegurar a satisfação da execução, escolhendo-se a medida menos gravosa se outra igualmente eficiente for disponível. No entanto, o devedor que invocar a menor onerosidade como 
argumento de defesa apenas será liberado da imposição da medida que se pretendia aplicar se indicar meio menos gravoso, mas igualmente eficaz.

De mais a mais, o princípio da patrimonialidade consigna que a execução é real, haja vista que somente o patrimônio do devedor é sujeito e pode satisfazer a execução, seja voluntariamente, seja mediante expropriação. A decorrência disso é que a medida coercitiva não pode encerrar um fim em si mesma, devendo, do contrário, servir estritamente à finalidade de fomentar a satisfação da execução.

$\mathrm{E}$, de acordo com o princípio da utilidade, essa capacidade de fomentar a satisfação da execução é até mesmo um requisito necessário à aplicação da medida coercitiva, pois, se não houver indícios de que a medida terá alguma eficácia, ela não poderá ser aplicada porque não será capaz de passar pelo teste da adequação. Por isso é que se deve observar a existência de sinais externos de riqueza ou elementos que apontem para a ocultação patrimonial, pois, se o devedor, de boa-fé, efetivamente não tiver patrimônio, a execução deverá se considerar frustrada, o que faz parte da vida em sociedade e principalmente do jogo empresarial. As medidas coercitivas estão reservadas aos devedores de má-fé, que possuem bens e não pagam a sua dívida porque não querem.

Nesse contexto, a propósito, vale o registro de que as medidas coercitivas atípicas não devem ser consideradas sanções civis de natureza material, haja vista que delas se distinguem pela função. As medidas coercitivas atípicas são espécie de sanção executiva, ou seja, são atos de execução que se prestam a realizar o resultado prático que o devedor não satisfez espontaneamente. Por isso, as medidas coercitivas atípicas devem ser capazes de fomentar a satisfação da execução, pois, do contrário, não serão admissíveis se simplesmente se revelarem como uma punição ao devedor.

É igualmente decorrência do princípio da proporcionalidade a necessidade de esgotamento dos meios típicos antes que se considere possível o emprego dos meios atípicos. O legislador estabeleceu procedimento típico a ser observado na execução, ao passo que os meios atípicos decorrem de uma cláusula geral cujo emprego depende da estrita observância da proporcionalidade. Assim sendo, enquanto não esgotados os meios típicos, naturalmente menos gravosos, não se poderá considerar como necessária qualquer medida atípica. Esse raciocínio, no entanto, não é aplicável à imposição das medidas de urgência, notadamente porque o juiz poderá determinar as medidas que considerar adequadas para 
efetivação da tutela provisória, incluindo-se, portanto, as medidas coercitivas atípicas.

Prosseguindo, como vimos, sendo função do juiz dirigir o processo, é possível a imposição, cassação ou modificação, de ofício, das medidas coercitivas atípicas, sendo discricionária, também, a escolha da medida a ser aplicada, inexistindo adstrição à medida porventura requerida pelo exequente.

Por fim, salvo para a restrição de liberdades, a revogação da medida coercitiva, em princípio, dependerá da satisfação da determinação imposta ao devedor, inexistindo, em princípio, um período máximo que determinada medida poderia estar vigente. O prazo de validade deverá ser adequado aos objetivos, o menos gravoso possível, razoável e, sobretudo, não poderá ser excessivo, cabendo ao juiz fixar o prazo que considerar suficiente e, também, revogar a medida imposta caso ela não se mostre eficaz.

Como palavras finais, esperamos que as proposições acima registradas sirvam como um guia para nortear o emprego das medidas coercitivas atípicas, propiciando a realização do ideal de efetividade, que inspirou e foi o objetivo maior para o legislador ordinário na criação do novo diploma processual, sempre com respeito aos direitos e garantias fundamentais, frutos de evolução histórica carregada de muita luta e maturação do pensamento humano. 


\section{REFERÊNCIAS}

ABELHA, Marcelo Rodrigues. O novo CPC e a tutela jurisdicional executiva (parte 1). Revista de processo, São Paulo v. 244, p. 87 150, jun. 2015. Disponível em: <https://www.revistadostribunais.com.br/maf/app/resultList/document?docguid =lb7af8000222311e5bdc5010000000000 >. Acesso em: 02 jan. 2018.

ABELHA, Marcelo. Manual de execução civil. 5aㅗ ed. Rio de Janeiro: Forense, 2015 [livro eletrônico].

ALEXY, Robert. Teoria dos direitos fundamentais. Tradução de Virgílio Afonso da Silva. São Paulo: Malheiros, 2008.

ALVIM, Angélica Arruda (coord.). Comentários ao código de processo civil. São Paulo: Saraiva, 2016.

AMARAL, Guilherme Rizzo. As astreintes e o processo civil brasileiro: multa do artigo 461 do CPC e outras. $2^{a}$ ed. Porto Alegre: Livraria do Advogado, 2010.

In OLIVEIRA, Carlos Alberto Álvaro de (coord.). A nova execução. Comentários à Lei n.ำ 11.232, de 22 de dezembro de 2005. Rio de Janeiro: Forense, 2006.

AMARAL, Moacyr Santos. Ações cominatórias no direito brasileiro. 5a ed. São Paulo: M. Limonad, 1973. v. 1.

AMENDOEIRA JR., Sidnei. As impenhorabilidades e a (não) efetividade da execução. In: ALVIM, Arruda et al (coords.). Execução civil e temas afins. São Paulo: Revista dos Tribunais, 2014.

. Execução, efetivação e cumprimento. In: BRUSCHI, Gilberto (coord.). Execução civil e cumprimento de sentença. São Paulo: Método, 2007. v. 2.

ANDRES, Neil. The system of enforcement of civil judgments in England. In: STURNER, Rolf. KAWANO, Masanori. (Coord.) Comparative studies on enforcement and provisional measures. Tubingen: Mohr Siebeck, 2011.

ASSIS, Araken de. Cabimento e adequação dos meios executórios "atípicos". In: TALAMINI, Eduardo; MINAMI, Marcos Youji (coords.). Medidas executivas atípicas. Salvador: JusPodivm, 2018.

[livro eletrônico].

Manual da execução. 18 ${ }^{\underline{a}}$ ed. São Paulo: Revista dos Tribunais, 2016

. O contempt of court no direito brasil. Revista de processo, São Paulo, v.

$\overline{111,} \quad$ p. 18-37, jul./set. 2003. Disponível em: <https://www.revistadostribunais.com.br/maf/app/resultList/document?\&docguid=I 3105f9202d5511e0baf30000855dd350>. Acesso em: 20 out. 2018.

ÁVILA, Humberto. Teoria dos princípios: da definição à aplicação dos princípios jurídicos. 16ª ed. São Paulo: Malheiros, 2015. 
AZEVEDO, Antonio Junqueira. Caracterização jurídica da dignidade da pessoa humana. Revista dos tribunais, São Paulo, v. 797, p. 11-26, mar. 2002. Disponível em <https://www.revistadostribunais.com.br/maf/app/resultList/document?docguid =If08381e0f25011dfab6f010000000000 >. Acesso em: 15 nov. 2019.

AZEVEDO, Júlio Camargo de; GAJARDONI, Fernando da Fonseca. Um novo capítulo na história das medidas executivas atípicas. Disponível em: https://www.jota.info/opiniao-e-analise/artigos/um-novo-capitulo-na-historia-dasmedidas-executivas-atipicas-11062018. Acesso em: 05 out. 2019.

BACELO, Joice. Devedores podem ter passaporte e carteira de habilitação apreendidos.

Disponível

em: <http://www.valor.com.br/legislacao/4661725/devedores-podem-ter-passaporte-ecarteira-de-habilitacao-apreendidos>. Acesso em: 08 de agosto de 2016.

BARIONI, Rodrigo. In: CABRAL, Antônio do Passo; CRAMER, Ronal (coord.). Comentários ao código de processo civil. $2^{\mathrm{a}}$ ed. Rio de Janeiro: Forense, 2016.

BARROSO, Luis Roberto. Curso de direito constitucional contemporâneo: os conceitos fundamentais e a construção do novo modelo. $5^{\mathrm{a}}$ ed. São Paulo: Saraiva, 2015.

Interpretação e aplicação da constituição: fundamentos de uma dogmática constitucional transformadora. 6ª ed. São Paulo: Saraiva, 2004.

BENETI, Sidnei Agostinho. Da conduta do juiz. 3ª ed. São Paulo: Saraiva, 2003.

BIBLIOTHĖQUE NATIONAL DE FRANCE. Code civil des français. Paris: De l'imprimerie de la république, $1804 . \quad$ Disponível em: <https://gallica.bnf.fr/ark:/12148/bpt6k1061517>. Acesso em: 18 out. 2018.

BONAVIDES, Paulo. Curso de direito constitucional. $5^{\text {a }}$ ed. São Paulo: Malheiros, 1994.

BORGES, Marcus Vinícius Motter. Medidas coercitivas atípicas nas execuções pecuniárias: parâmetros para a aplicação do art. 139, IV do CPC/15. São Paulo: Thomsom Reuters Brasil, 2019.

BRASIL. Constituição da República Federativa do Brasil de 1988. Constituição Federal. Disponível em: <http://www.planalto.gov.br/ccivil_03/constituicao/constitu icao.htm>. Acesso em: 26 jun. 2018.

BRASIL. Decreto n. 592, de 06 de julho de 1992. Pacto Internacional sobre Direitos Civis e Políticos. Disponível em: <http://www.planalto.gov.br/ccivil_03/decreto/1990-1994/D0592.htm>. Acesso em: 02. dez. 2019.

BRASIL. Decreto n.․ 678, de 6 de novembro de 1992. Convenção Americana sobre Direitos Humanos (Pacto de São José da Costa Rica). Disponível em $<$ http://www.planalto.gov.br/ccivil_03/decreto/D0678.htm>. Acesso em: 02. dez. 2019. 
BRASIL. Decreto-Lei n. 1.608 , de 18 de setembro de 1939. Código de Processo Civil, 1939. Disponível em: <http://www.planalto.gov.br/ccivil_03/Leis/L5869impre ssao.htm>. Acesso em: 26 jun. 2018.

BRASIL. Lei 11.382, de 6 de dezembro de 2006. Altera dispositivos da Lei no 5.869, de 11 de janeiro de 1973 - Código de Processo Civil, relativos ao processo de execução e a outros assuntos. Disponível em: <http://www.planalto.gov.br/ccivil_03/_Ato2004-2006/2006/Lei/L11382.htm>.

BRASIL. Lei n.․ 10.444, de 7 de maio de 2002. Altera a Lei no 5.869, de 11 de janeiro de 1973 - Código de Processo Civil., 2002. Disponível em: <http://www.planalto.gov.br/ccivil_03/Leis/2002/L10444.htm\#art461\%C2\%A75>.

BRASIL. Lei n. -11.232 , de 22 de dezembro de 2005. Altera a Lei no 5.869, de 11 de janeiro de 1973 - Código de Processo Civil, para estabelecer a fase de cumprimento das sentenças no processo de conhecimento e revogar dispositivos relativos à execução fundada em título judicial, e dá outras providências, 2005.2 Disponível em: <http://www.planalto.gov.br/ccivil_03/_Ato2004-2006/2005/Lei/L11232.htm>.

BRASIL. Lei n.․ 13.105, de 16 de março de 2015. Código de Processo Civil, 2015. Disponível em: <http://www.planalto.gov.br/ccivil_03/_ato20152018/2015/lei/l13105.htm>. Acesso em: 26 jun. 2018.

BRASIL. Lei n. 5.869, de 11 de janeiro de 1973. Código de Processo Civil, 1973. Disponível em: <http://www.planalto.gov.br/ccivil_03/Leis/L5869impressao.htm>. Acesso em: 26 jun. 2018.

BRASIL. Lei n.ำ 5.869, de 11 de janeiro de 1973 - Publicação original. Código de processo civil, 1973.10 Disponível <http://www2.camara.leg.br/legin/fed/lei/1970-1979/lei-5869-11-janeiro-1973357991-publicacaooriginal-1-pl.html>. Acesso em: 26 jun. 2018.

BRASIL. Lei n.. 8.952, de 13 de dezembro de 1994. Altera dispositivos do Código de Processo Civil sobre o processo de conhecimento e o processo cautelar, 1994. Disponível em: <http://www.planalto.gov.br/ccivil_03/Leis/L8952.htm>. Acesso em: 26 jun. 2018.

BRASIL. Lei n.. 8.953, de 13 de dezembro de 1994. Altera dispositivos do Código de Processo Civil relativos ao processo de execução. Disponível em: <http://www.planalto.gov.br/ccivil_03/LEIS/L8953.htm>. Acesso em: 28 jun. 2018.

Brasil. Lei no 10.406, de 10 de janeiro de 200. Código civil de 2002. Disponível em $<$ http://www.planalto.gov.br/ccivil_03/leis/2002/110406.htm>. Acesso em: 18 out. 2018.

Brasil. Lei oㅜ 3.071, de 1ํ de janeiro de 1916. Código civil de 1916. Disponível em: <http://www.planalto.gov.br/ccivil_03/LEIS/L3071impressao.htm>. Acesso em: 18. out. 2018.

BRASIL. Superior Tribunal de Justiça. Agravo interno no agravo em recurso especial 1.233.016 - SP. Relator: Ministro Marco Aurélio Belizze. Brasília. J. em: 
10/04/2018. Disponível em: <https://ww2.stj.jus.br/processo/revista/documento/me diado/ ?componente $=$ ITA\&sequencial $=1697610 \&$ num_registro $=201800090023 \& d a$ ta=20180417\&formato=PDF>. Acesso em: 05 out. 2019.

BRASIL. Superior Tribunal de Justiça. Agravo interno no recurso especial 1.785.726 - DF. Relator: Marco Aurélio Bellizze. Brasília. J. em: 19/08/2019. Disponível em:<https://ww2.stj.jus.br/processo/julgamento/eletronico/documento/ mediado/?documento_tipo=integra\&documento_sequencial=99910722\&registro_n umero $=201801276127 \&$ publicacao_data $=20190822 \&$ formato=PDF $>$. Acesso em: 05 out. 2019.

BRASIL. Superior Tribunal de Justiça. Habeas corpus 411.519 - SP. Relator: Ministro Moura Ribeiro. Brasília. J. em: 21/09/2017. Disponível em: $<$ https://ww2.stj.jus.br/processo/revista/documento/mediado/?componente=ITA\&s equencial $=1636795 \&$ num_registro $=201701980037 \&$ data $=20171003 \&$ formato $=P D$ F>. Acesso em: 19 out. 2019.

BRASIL. Superior Tribunal de Justiça. Habeas corpus 422.699 - SP. Relatora: Ministra Nancy Andrighi. Brasília. J. em: 26/06/2018. Disponível em:<https://ww2.stj.jus.br/processo/revista/documento/mediado/?componente=IT A\&sequencial $=1729669 \&$ num_registro $=201702813307 \&$ data $=20180629 \&$ formato $=$ PDF $>$. Acesso em: 05 out. 2019 .

BRASIL. Superior Tribunal de Justiça. Recurso em habeas corpus 97.876 - SP. Relator: Ministro Luis Felipe Salomão. Brasília. J. em: 05/06/2018. Disponível em:<https://ww2.stj.jus.br/processo/revista/documento/mediado/?componente=IT A\&sequencial $=1719447 \&$ num_registro $=201801040236 \&$ data $=20180809 \&$ formato $=$ PDF $>$. Acesso em: 05 out. 2019.

BRASIL. Superior Tribunal de Justiça. Recurso em habeas corpus 99.606 - SP. Relatora: Ministra Nancy Andrighi. Brasília. J. em: 13/11/2018. Disponível em:<https://ww2.stj.jus.br/processo/revista/documento/mediado/?componente=IT A\&sequencial $=1772094 \&$ num_registro $=201801506719 \&$ data $=20181120 \&$ formato =PDF>. Acesso em: 05 out. 2019.

BRASIL. Superior Tribunal de Justiça. Recurso especial 1.334.635 - RS. Relator: Ministro Antonio Carlos Ferreira. Brasília. J. em: 19/09/2019. Disponível em: $<$ https://ww2.stj.jus.br/processo/revista/documento/mediado/?componente=ITA\&s equencial $=1866265 \&$ num_registro $=201201487665 \&$ data $=20190924 \&$ formato $=P D$ F>. Acesso em: 31 out. 2019.

BRASIL. Superior Tribunal de Justiça. Recurso especial 1.782.418 - RJ. Relatora: Ministra Nancy Andrighi. Brasília. J. em: 23/04/2019. Disponível em:<https://ww2.stj.jus.br/processo/revista/documento/mediado/?componente=IT A\&sequencial $=1817993 \&$ num_registro $=201803135957 \&$ data $=20190426 \&$ formato $=$ PDF $>$. Acesso em: 05 out. 2019.

BRASIL. Superior Tribunal de Justiça. Recurso especial 1.788.950 - MT. Relatora: Ministra Nancy Andrighi. Brasília. J. em: 23/04/2019. Disponível em:<https://ww2.stj.jus.br/processo/revista/documento/mediado/?componente=IT 
A\&sequencial $=1818004 \&$ num_registro $=201803438355 \&$ data $=20190426 \&$ formato $=$ PDF $>$. Acesso em: 05 out. 2019.

BRASIL. Superior Tribunal de Justiça. Recurso especial 1.825.053 - PR. Relator: Ministro Herman Benjamin. Brasília. J. em 27/08/2019. Disponível em <https://ww2.stj.jus.br/processo/revista/documento/mediado/?componente=ITA\&s equencial $=1857654 \&$ num_registro $=201901973839 \&$ data $=20190905 \&$ formato $=P D$ F>. Acesso em: 27 nov. 2019.

BRASIL. Supremo Tribunal Federal. Reclamação 1.722 - RJ. Relator: Ministro Celso de Mello. J. em: 26/02/2003. Disponível em $<$ http://redir.stf.jus.br/paginadorpub/paginador.jsp?docTP=AC\&doclD=87190>. Acesso em: 14 fev. 2018.

BRASIL. Supremo Tribunal Federal. Recurso extraordinário 201.819 - RJ. Relator: Ministro Gilmar Mendes. Brasília. J. em: 11/10/2005. Disponível em: $<$ http://redir.stf.jus.br/paginadorpub/paginador.jsp?docTP=AC\&doclD=388784>. Acesso em: 01 jan. 2020.

BRASIL. Supremo Tribunal Federal. Recurso extraordinário 466.343-1 - SP. Relator: Min. Cezar Peluso. Brasília. J. em: 03/12/2008. Disponível em $<$ http://redir.stf.jus.br/paginadorpub/paginador.jsp?docTP=AC\&doclD=595444>. Acesso em: 02. dez. 2019.

BRASIL. Tribunal de Justiça do Estado de São Paulo. Agravo de instrumento 2023416 02.2019.8.26.0000. Relatora: Des. Denise Andréa Martins Retamero. Disponível em <https://esaj.tjsp.jus.br/cjsg/getArquivo.do?conversationld=\&cdAcor dao $=12830105 \&$ cdForo $=0>$. Acesso em: 04 jan. 2020.

BRASIL. Tribunal de Justiça do Estado de São Paulo. Agravo de instrumento 2051214-35.2019.8.26.0000. Relator: Des. Hamid Bdine. Disponível em <https://esaj.tjsp.jus.br/cjsg/getArquivo.do?cdAcordao=12653314\&cdForo=0>. Acesso em: 10 set. 2019.

BRASIL. Tribunal de Justiça do Estado de São Paulo. Agravo de instrumento 2060589-60.2019.8.26.0000. Relator: Des. Maia da Rocha. Disponível em <https://esaj.tjsp.jus.br/cjsg/resultadoCompleta.do>. Acesso em: 10 set. 2019.

BRASIL. Tribunal de Justiça do Estado de São Paulo. Agravo de instrumento 2070292 15.2019.8.26.0000. Relator: Des. Fernando Sastre Redondo. Disponível em <https://esaj.tjsp.jus.br/cjsg/getArquivo.do?cdAcordao=12800676\&cdForo=0>. Acesso em: 10 set. 2019.

BRASIL. Tribunal de Justiça do Estado de São Paulo. Agravo de instrumento 2071709 03.2019.8.26.0000. Relator: Des. Maia da Rocha. Disponível em $<$ https://esaj.tjsp.jus.br/cjsg/getArquivo.do?cdAcordao=12649980\&cdForo=0>. Acesso em: 10 set. 2019.

BRASIL. Tribunal de Justiça do Estado de São Paulo. Agravo de instrumento 2072883 47.2019.8.26.0000. Relatora: Des. Cristina Zucchi. Disponível em <https://esaj.tjsp.jus.br/cjsg/getArquivo.do?cdAcordao=12599039\&cdForo=0 $>$.

Acesso em: 10 set. 2019. 
BRASIL. Tribunal de Justiça do Estado de São Paulo. Agravo de instrumento 2075552-73.2019.8.26.0000. Relator: Des. Virgilio de Oliveira Junior. Disponível em <https://esaj.tjsp.jus.br/cjsg/getArquivo.do?cdAcordao $=12676179 \&$ cdForo=0 $>$. Acesso em: 10 set. 2019.

BRASIL. Tribunal de Justiça do Estado de São Paulo. Agravo de instrumento 2087169 30.2019.8.26.0000. Relator: Des. Ricardo Pessoa de Mello Belli. Disponível em <https://esaj.tjsp.jus.br/cjsg/getArquivo.do?cdAcordao=12800881\& cdForo=0 $>$. Acesso em: 10 set. 2019.

BRASIL. Tribunal de Justiça do Estado de São Paulo. Agravo de instrumento 2091597 55.2019.8.26.0000. Relator: Des. Walter Barone. Disponível em $<$ https://esaj.tjsp.jus.br/cjsg/getArquivo.do?cdAcordao $=12640513 \&$ cdForo $=0>$. Acesso em: 10 set. 2019.

BRASIL. Tribunal de Justiça do Estado de São Paulo. Agravo de instrumento 2091917-08.2019.8.26.0000. Relator: Des. Hugo Crepaldi. Disponível em $<$ https://esaj.tjsp.jus.br/cjsg/getArquivo.do?cdAcordao=12625307\&cdForo=0>. Acesso em: 10 set. 2019.

BRASIL. Tribunal de Justiça do Estado de São Paulo. Agravo de instrumento 2093760-08.2019.8.26.0000. Relator: Des. Renato Rangel Desinano. Disponível em <https://esaj.tjsp.jus.br/cjsg/getArquivo.do?cdAcordao=12662240\&cdForo=0>. Acesso em: 04 jan. 2020.

BRASIL. Tribunal de Justiça do Estado de São Paulo. Agravo de instrumento 2097817-69.2019.8.26.0000. Relator: Des. Hamid Bdine. Disponível em <https://esaj.tjsp.jus.br/cjsg/getArquivo.do?cdAcordao=12682411\&cdForo=0 . Acesso em: 10 set. 2019.

BRASIL. Tribunal de Justiça do Estado de São Paulo. Agravo de instrumento 2099490-97.2019.8.26.0000. Relator: Des. Maia da Rocha. Disponível em $<$ https://esaj.tjsp.jus.br/cjsg/getArquivo.do?cdAcordao=12791208\&cdForo=0 $>$. Acesso em: 10 set. 2019.

BRASIL. Tribunal de Justiça do Estado de São Paulo. Agravo de instrumento 2103856-82.2019.8.26.0000. Relator: Des. César Peixoto. Disponível em $<$ https://esaj.tjsp.jus.br/cjsg/getArquivo.do?cdAcordao $=12629281 \&$ cdForo=0 $>$. Acesso em: 10 set. 2019.

BRASIL. Tribunal de Justiça do Estado de São Paulo. Agravo de instrumento 2111953-71.2019.8.26.0000. Relator: Des. Walter Barone. Disponível em $<$ https://esaj.tjsp.jus.br/cjsg/getArquivo.do?cdAcordao=12724256\&cdForo=0>. Acesso em: 10 set. 2019.

BRASIL. Tribunal de Justiça do Estado de São Paulo. Agravo de instrumento 2114659-27.2019.8.26.0000. Relator: Des. Paulo Pastore Filho. Disponível em <https://esaj.tjsp.jus.br/cjsg/getArquivo.do?cdAcordao=12759456\&cdForo=0>. Acesso em: 10 set. 2019.

BRASIL. Tribunal de Justiça do Estado de São Paulo. Agravo de instrumento 2120340-75.2019.8.26.0000. Relator: Des. Melo Colombi. Disponível em 
$<$ https://esaj.tjsp.jus.br/cjsg/getArquivo.do?cdAcordao=12655678\&cdForo=0 $>$. Acesso em: 10 set. 2019.

BRASIL. Tribunal de Justiça do Estado de São Paulo. Agravo de instrumento 2121972-39.2019.8.26.0000. Relator: Des. Achile Alesina. Disponível em <https://esaj.tjsp.jus.br/cjsg/getArquivo.do?cdAcordao=12761678\&cdForo=0>. Acesso em: 10 set. 2019.

BRASIL. Tribunal de Justiça do Estado de São Paulo. Agravo de instrumento 2122199-29.2019.8.26.0000. Relator: Des. Souza Lopes. Disponível em <https://esaj.tjsp.jus.br/cjsg/getArquivo.do?cdAcordao=12761678\&cdForo=0>. Acesso em: 10 set. 2019.

BRASIL. Tribunal de Justiça do Estado de São Paulo. Agravo de instrumento 2123852-66.2019.8.26.0000. Relator: Des. Achile Alesina. Disponível em $<$ https://esaj.tjsp.jus.br/cjsg/getArquivo.do?cdAcordao=12621565\&cdForo=0 $>$. Acesso em: 10 set. 2019.

BRASIL. Tribunal de Justiça do Estado de São Paulo. Agravo de instrumento 2129894-34.2019.8.26.0000. Relator: Des. Virgilio de Oliveira Junior. Disponível em <https://esaj.tjsp.jus.br/cjsg/getArquivo.do?cdAcordao $=12703361 \&$ cdForo $=0>$. Acesso em: 10 set. 2019.

BRASIL. Tribunal de Justiça do Estado de São Paulo. Agravo de instrumento 2131362-33.2019.8.26.0000. Relator: Des. Irineu Fava. Disponível em <https://esaj.tjsp.jus.br/cjsg/getArquivo.do?cdAcordao=12824292\&cdForo=0 >. Acesso em: 10 set. 2019.

BRASIL. Tribunal de Justiça do Estado de São Paulo. Agravo de instrumento 2148908-04.2019.8.26.0000. Relator: Des. Coutinho de Arruda. Disponível em <https://esaj.tjsp.jus.br/cjsg/getArquivo.do?cdAcordao=12659008\&cdForo=0 $>$. Acesso em: 04 jan. 2020.

BRASIL. Tribunal de Justiça do Estado de São Paulo. Agravo de instrumento 2150272-11.2019.8.26.0000. Relator: Des. Fernando Sastre Redondo. Disponível em <https://esaj.tjsp.jus.br/cjsg/getArquivo.do?cdAcordao=12761123\&cdForo=0>. Acesso em: 10 set. 2019.

BRASIL. Tribunal de Justiça do Estado de São Paulo. Agravo de instrumento 2150454-94.2019.8.26.0000. Relatora: Des. Lígia Araújo Bisogni. Disponível em $<$ https://esaj.tjsp.jus.br/cjsg/getArquivo.do?cdAcordao $=12818588 \& c d F o r o=0>$. Acesso em: 10 set. 2019.

BRASIL. Tribunal de Justiça do Estado de São Paulo. Agravo de instrumento 2152635-68.2019.8.26.0000. Relator: Des. Ruy Coppola. Disponível em $<$ https://esaj.tjsp.jus.br/cjsg/getArquivo.do?cdAcordao=12764521\&cdForo=0 $>$. Acesso em: 10 set. 2019.

BRASIL. Tribunal de Justiça do Estado de São Paulo. Agravo de instrumento 2156407-39.2019.8.26.0000. Relator: Des. Mario de Oliveira. Disponível em <https://esaj.tjsp.jus.br/cjsg/getArquivo.do?cdAcordao=12782307\&cdForo=0>.

Acesso em: 04 jan. 2020. 
BRASIL. Tribunal de Justiça do Estado de São Paulo. Agravo de instrumento 2169337-89.2019.8.26.0000. Relator: Des. Achile Alesina. Disponível em $<$ https://esaj.tjsp.jus.br/cjsg/getArquivo.do?cdAcordao=12791988\&cdForo=0 > . Acesso em: 10 set. 2019.

BRASIL. Tribunal de Justiça do Estado de São Paulo. Agravo de instrumento 2178308-63.2019.8.26.0000. Relator: Des. Gilberto dos Santos. Disponível em $<$ https://esaj.tjsp.jus.br/cjsg/getArquivo.do?cdAcordao $=12828995 \& \mathrm{cdForo}=0>$. Acesso em: 04 jan. 2020.

BRASIL. Tribunal de Justiça do Estado de São Paulo. Agravo de instrumento 2248190-49.2018.8.26.0000. Relator: Des. Roberto Mac Cracken. Disponível em $<$ https://esaj.tjsp.jus.br/cjsg/getArquivo.do?cdAcordao $=12662352 \&$ cdForo $=0>$. Acesso em: 10 set. 2019.

BRASIL. Tribunal de Justiça do Estado de São Paulo. Agravo de instrumento 2266747 84.2018.8.26.0000. Relator: Des. Coutinho de Arruda. Disponível em $<$ https://esaj.tjsp.jus.br/cjsg/getArquivo.do?cdAcordao $=12659008 \&$ cdForo $=0>$.

Acesso em: 04 jan. 2020.

BUENO, Cassio Scarpinella. Manual de direito processual civil. São Paulo: Saraiva, 2015.

CÂMARA, Alexandre Freitas de. A nova execução de sentença. $3^{a}$ ed. Rio de Janeiro: Lumen Juris, 2007.

O princípio da patrimonialidade da execução e os meios executivos atípicos: lendo o art. 139, IV, do CPC. In: TALAMINI, Eduardo; MINAMI, Marcos Youji (coords.). Medidas executivas atípicas. Salvador: JusPodivm, 2018.

A eficácia da execução e a eficiência dos meios executivos. In: ALVIM, $\overline{\text { Arruda }}$ et al (coords.). Execução civil e temas afins. São Paulo: Revista dos Tribunais, 2014.

CAMBI, Eduardo; HAAS, Adriane; SCHMITZ, Nicole. Princípio da cooperação processual e o novo CPC. Revista dos Tribunais, São Paulo, v. 987, p. 345-384, out. $2017 . \quad$ Disponível em $<$ https://www.revistadostribunais.com.br/maf/app/resultList/document?docguid=lb6 1343d0a01611e78630010000000000 >. Acesso em: 02 jan. 2018.

CAMBI, Eduardo; PADILHA, Elisângela. Dimensões da dignidade da pessoa humana. Revista de direito privado, São Paulo, v. 71, p. 111-128, nov. 2016. Disponível em: <https://www.revistadostribunais.com.br/maf/app/resultList/docume nt?\&docguid=I5a35761094ea11 e689b6010000000000 > . Acesso em: 15 nov. 2019.

CANCIAN, Natália. Juízes suspendem CNH e passaporte de devedores para acelerar pagamento.

Disponível

em: $<$ https://www1.folha.uol.com.br/cotidiano/2018/05/juizes-suspendem-cnh-epassaporte-de-devedores-para-acelerar-pagamento.shtml>. Acesso em: 29 de maio de 2018. 
CANOTILHO, José Joaquim Gomes; MOREIRA, Vital. Fundamentos da Constituição. Coimbra: Coimbra Editora, 1991.

CAPPELLETI, Mauro; GARTH, Bryant. Acesso à justiça. Tradução de Ellen Gracie Northfleet. Porto Alegre: Sergio Antonio Fabris Editor, 1988.

CARNELUTTI, Francesco. Instituciones del processo civil. Tradução de Santiago Sentís Melendo. Buenos Aires: El Foro, 1997. v. 1.

Processo di esecuzione. Padova: CEDAM. 1932. v. 1.

CARREIRA, Guilherme Sarri. Dos poderes do juiz na execução por quantia certa: da utilização das medidas inominadas. In: TALAMINI, Eduardo; MINAMI, Marcos Youji (coords.). Medidas executivas atípicas. Salvador: JusPodivm, 2018.

CHIOVENDA, Giuseppe. Instituições de direito processual civil. Tradução de Paolo Capitanio. 4ํㅡㄹ ed. Campinas: Bookseller, 2009.

CINTRA, Antônio Carlos de Araujo; GRINOVER, Ada Pellegrini; DINAMARCO, Cândido Rangel. Teoria geral do processo. 24를 ed. São Paulo: Malheiros, 2008.

CLÈVE, Clemerson Mèrlin. O controle de constitucionalidade e a efetividade dos direitos fundamentais. In: SAMPAIO, José Adércio Leite (coord.). Jurisdição e constitucional e direitos fundamentais. Belo Horizonte: Del Rey, 2003.

COMISSÃO DE JURISTAS RESPONSÁVEL PELA ELABORAÇÃO DO ANTEPROJETO DO NOVO CÓDIGO DE PROCESSO CIVIL. Anteprojeto do novo código de processo civil. Brasília: Senado Federal, Subsecretaria de Edições $\quad 2010 . \quad$ Técnicas, Disponível em: <http://www2.senado.leg.br/bdsf/handle/id/496296>. Acesso em: 02 out. 2019.

COMOGLIO, Luigi Paolo. Giurisdizione e processo nel quadro dele garanzie costituzionali. Studi in onore di Luigi Montesano. Padova: Cedam, 1997. v. 2.

CONSELHO NACIONAL DE JUSTIÇA. Justiça em números 2019. Brasília: CNJ, 2019.

CONSELHO NACIONAL DE JUSTIÇA. Metas nacionais para 2019. Disponível em <https://www.cnj.jus.br/wp-content/uploads/2019/08/6bc995b76a92dd1823bef8b9 a4fc51dd.pdf>. Acesso em: 26 dez. 2019.

COORDENAÇÃO DE EDIÇÕES TÉCNICAS. Código de processo civil e normas correlatas. $11^{\underline{a}}$ ed. Brasília: Senado Federal, 2017. Disponível em: <https://www2.senado.leg.br/bdsf/bitstream/handle/id/531491/cpc_11ed.pdf>. Acesso em: 17 ago. 2019.

COSTA, Alfredo de Araújo Lopes da. Direito processual civil brasileiro. $2^{\underline{a}}$ ed. Rio de Janeiro: Forense, 1959. v. 4.

CUNHA, Leonardo José Carneiro da. Princípio da proporcionalidade na execução civil. In: BRUSCHI, Gilberto (coord.). Execução civil e cumprimento de sentença. São Paulo: Método, 2006. v. 1. 
CUNHA, Luciana Gross el al. Relatório ICJBrasil - 10 semestre / 2016. Disponível em <http://bibliotecadigital.fgv.br/dspace/bitstream/handle/10438/17204/Relatorio ICJBrasil_1_sem_2016.pdf>. Acesso em: 04 nov. 2018.

DEU, Teresa Armenta. Ejecución y medidas conminativas personales. Un estudio comparado. Revista de derecho, Coquimbo, v. 22, n. 2, p. 23-54, 2015. Disponível em: $\quad<h t t p s: / / s c i e l o . c o n i c y t . c l / s c i e l o . p h p ? s c r i p t=s c i \_a r t t e x t \& p i d=S 0718$ 97532015000200002\&lng=en\&nrm=iso>. Acesso em: 15 nov. 2019.

DIDIER JR., Fredie. Curso de direito processual civil: introdução ao direito processual civil, parte geral e processo de conhecimento. $17^{a}$ ed. Salvador: JusPodivm, 2015. v. 1.

. Esboço de uma teoria da execução civil. Revista de processo, São Paulo, v. 118, p. 9-28, nov./dez. 2004. Disponível em: $<$ https://www.revistadostribunais.com.br/maf/app/resultList/document?\&docguid=I b70786f0f25511dfab6f010000000000 >. Acesso em: 25 jun. 2019.

DIDIER JR., Fredie et al. Curso de direito processual civil. 20 ed. Salvador: JusPodivm, 2018. v. 5.

DIDIER JR., Fredie et al. Diretrizes para a concretização das cláusulas gerais executivas dos arts. 139, inciso IV, 297 e 536, §1ํㅡㄹ do CPC. In: TALAMINI, Eduardo; MINAMI, Marcos Youji (coords.). Medidas executivas atípicas. Salvador: JusPodivm, 2018.

DINAMARCO, Cândido Rangel. A instrumentalidade do processo. 10ª ed. São Paulo: Malheiros, 2002.

A reforma do código de processo civil. São Paulo: Malheiros, 1995.

Execução civil. 6ª ed. São Paulo: Malheiros, 1998.

2009. v. 4.

Instituições de direito processual civil. $3^{\underline{a}}$ ed. São Paulo: Malheiros,

; LOPES, Bruno Vasconcelos Carrilho. Teoria geral do novo processo civil. São Paulo: Malheiros, 2016.

DINIZ, Maria Helena. Conceito de norma jurídica como problema de essência. $4^{a}$ ed. São Paulo: Saraiva, 2003.

DURO, Cristiano. Execução e democracia: a tutela executiva no processo constitucional. Salvador: JusPodivm, 2018.

DWORKIN, Ronald. Levando os direitos a sério. Tradução de Nelson Boeira. São Paulo: Martins Fontes, 2002.

FERREIRA FILHO, Manoel Gonçalves. Curso de direito constitucional. 38ª ed. São Paulo: Saraiva, 2012.

FÓRUM PERMANENTE DE PROCESSUALISTAS CIVIS. Carta de Recife, 2018. 
FREDERICO MARQUES, José. Manual de direito processual civil. 13ª ed. São Paulo: Saraiva, 1990. v. 1.

FUX, Luiz. Curso de direito processual civil. Rio de Janeiro: Forense, 2004.

GAJARDONI, Fernando da Fonseca. A revolução silenciosa da execução por quantia. Disponível em: <https://www.jota.info/opiniao-e-analise/artigos/arevolucao-silenciosa-da-execucao-por-quantia-24082015>. Acesso em: 03 mai. de 2018.

GAJARDONI, Fernando da Fonseca; PEREIRA, Augusto Martins. Medidas atípicas na execução civil: análise de casos no âmbito do TJSP. In: MARCATO, Ana Cândida Menezes et al. Reflexões sobre o código de processo civil de 2015. São Paulo: Verbatim, 2018.

GAJARDONI, Fernando da Fonseca et al. Teoria geral do processo. Comentários ao CPC de 2015. Parte Geral. São Paulo: Método, 2016.

GALLI, Marcelo. Juíza suspende CNH de devedor para garantir pagamento de dívida. Disponível em: <https://www.conjur.com.br/2016-nov-08/juiza-suspendecnh-devedor-garantir-pagamento-divida>. Acesso em: 13 de junho de 2018.

GRECO, Leonardo. A execução e a efetividade do processo. Revista de processo, São Paulo, v. 94, p. 34 66, abr./jun. 1999. Disponível em: $<$ https://www.revistadostribunais.com.br/maf/app/resultList/document?docguid=19a 34c3b0f25711dfab6f010000000000 >. Acesso em: 25 jan. 2019.

Coações indiretas na execução pecuniária. Revista da EMERJ, Rio de Janeiro, v. 20, n. 1, p. 109-134, jan./abr. 2018.

O processo de execução. Rio de Janeiro: Renovar, 1999. v. 1.

GRINOVER, Ada Pelegrini. Tutela jurisdicional nas obrigações de fazer ou não fazer. In: TEIXEIRA, Sálvio de Figueiredo (coord.). Reforma do código de processo civil. São Paulo: Saraiva, 1996.

Ensaio sobre a processualidade: fundamentos para uma nova teoria geral do processo. Brasília: Gazeta Jurídica, 2016.

Os princípios constitucionais e o código de processo civil. São Paulo: José Bushatsky Editor, 1975.

GUERRA FILHO, Willis Santiago. Ensaios de teoria constitucional. Fortaleza: Imprensa Universitária, 1989.

GUERRA, Marcelo Lima. Direitos fundamentais e a proteção do credor na execução civil. São Paulo: Revista dos Tribunais, 2003.

. Execução indireta. São Paulo: Revista dos Tribunais, 1998. 
. Inovações na execução direta das obrigações de fazer e não fazer. In: WAMBIER, Teresa Arruda Alvim (coord.). Processo de execução e assuntos afins. São Paulo: Revista dos Tribunais, 1998.

HESSE, Konrad. Escritos de derecho constitucional. Madrid: Centro de Estudios Constitucionales, 1983.

Kant, Emmanuel. Fundamentação da metafísica dos costumes. Tradução de Paulo Quintela. Lisboa: Edições 70, 2007.

KENNETT, Wendy. Enforcement of judgments in Europe. Nova lorque: Oxford University Press Inc., 2000.

LEMOS, Vinicius Silva. A penhora e sua função neutralizadora ao art. 139, IV, do CPC e as medidas atípicas. Revista de direito privado, São Paulo, v. 87, p. 123148, mar. 2018. Disponível em <https://www.revistadostribunais.com.br/maf/app/resultList/document?docguid=la5 3156f0248311e8b6a3010000000000 >. Acesso 10. mar. 2019.

LIEBMAN, Enrico Tullio. Processo de execução. 4aㅡ ed. São Paulo: Saraiva, 1980. LOPES DA COSTA, Alfredo Araújo. Direito processual civil brasileiro. $2^{\underline{a}}$ ed. Rio de Janeiro: Forense, 1959. v. 4.

MANCUSO, Rodolfo de Camargo. Acesso à justiça. 2ª ed. São Paulo: Revista dos Tribunais, 2015 [livro eletrônico]. Disponível em <https://proview.thomsonreuters.com/>. Acesso em: 04 nov. 2018.

MARINONI, Luiz Guilherme. Ausência de fundamentos para a redução do valor da multa. Soluções práticas, São Paulo, v. 2, p. 275-291, out. 2011. Disponível em: $<$ https://www.revistadostribunais.com.br/maf/app/resultList/document?\&src=rl\&doc guid=la81f8de0e50b11e6a673010000000000 >. Acesso em: 02 jan. 2018.

. Controle do poder executivo do juiz. In: DIDIER JR., Fredie. Execução civil: estudos em homenagem ao professor Paulo Furtado. Rio de Janeiro: Lumen Juris, 2006.

$\begin{array}{lll}\text { direitos } & \text { direito à tutela jurisdicional efetiva na perspectiva da teoria dos } \\ \text { fundamentais. } & \text { Disponível }\end{array}$ http://egov.ufsc.br/portal/sites/default/files/anexos/15441-15442-1-PB.pdf. Acesso em: 19 nov. 2018.

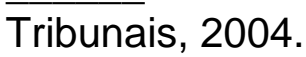

Técnica processual e tutela dos direitos. São Paulo: Revista dos ; ARENHART, Sérgio Cruz; MITIDIERO, Daniel. Novo curso de processo civil. São Paulo: Revista dos Tribunais, 2015. v. 2.

MARQUES, José Frederico. Manual de direito processual civil: processo de execução e cautelar (parte geral). Campinas: Bookseller, 1997. v. 4. 
MEDEIROS NETO, Elias Marque de; REINAS, Caroline Pastri Pinto. A aplicação das medidas executivas atípicas do artigo 139, inciso IV, do CPC/2015 pelo Tribunal de Justiça do Estado de São Paulo. Revista de Processo, São Paulo, v. 286, p. 277-297, dez. 2018. Disponível em: <https://www.revistadostribunais.com.br/maf/app/resultList/document?\&docguid=I c2b6c570e24c11e886f0010000000000 >. Acesso em: 05 out. 2019.

MEDINA, José Miguel Garcia. Direito processual civil moderno. $2^{\underline{a}}$ ed. São Paulo: Revista dos Tribunais, 2016.

MEDINA, José Miguel Garcia. Novo código de processo civil comentado. 4⿳丷a ed. São Paulo: Revista dos Tribunais, 2016.

MEIRELES, Edilton. Cooperação judicial e poderes do juiz na execução. In: TALAMINI, Eduardo; MINAMI, Marcos Youji (coords.). Medidas executivas atípicas. Salvador: JusPodivm, 2018.

MENDES, Gilmar Ferreira. Direitos fundamentais e controle de constitucionalidade: estudos de direito constitucional. $2^{a}$ ed. São Paulo: Celso Bastos: Instituto Brasileiro de Direito Constitucional, 1999.

MINAMI, Marcos Youji. Breves apontamentos sobre a generalização das medidas de efetivação no CPC/2015 do processo para além da decisão. In: DIDIER JR., Fredie et al (coord.). Novo CPC doutrina selecionada, $1^{\underline{a}}$ ed. Salvador: JusPodivm, 2015. v. 5.

. Uma justificativa às medidas executivas atípicas atípicas - da vedação ao non factible. In: TALAMINI, Eduardo; MINAMI, Marcos Youji (coords.). Medidas executivas atípicas. Salvador: JusPodivm, 2018.

; NOGUEIRA, Natália Viana; MOREIRA, Orquídea Sampaio. Uma análise das decisões dos tribunais brasileiros acerca da atipicidade dos meios executivos à luz do art. 139, IV, do CPC/2015. Revista de processo, São Paulo, v. 281, p. 593-622, jul. 2018. Disponível em <https://www.revistadostribunais.com.br/maf/app/resultList/document?\&docguid=I 40e61b706ae411e8a503010000000000>. Acesso em: 15 nov. 2019.

MIRANDA, Vicente. Poderes do juiz no processo civil brasileiro. São Paulo: Saraiva, 1992.

MITIDIERO, Daniel. Direito fundamental à tutela jurisdicional adequada e efetiva. In: BRUSCHI, Gilberto (coord.). Execução civil e cumprimento de sentença. São Paulo: Método, 2009. v. 3.

MOREIRA, José Carlos Barbosa. Notas sobre o problema da "efetividade" do processo. Revista Ajuris, Porto Alegre, v. 10, n. 29, p. 77-94, nov. 1983.

Os novos rumos do processo civil brasileiro. Revista de processo, São Paulo, v. 20, n. 78, p. 133-144, abr./jun. 1995.

Temas de direito processual: quarta série. São Paulo: Saraiva, 1989. 
. Temas de direito processual: segunda série. São Paulo: Saraiva, 1980.

NERY JUNIOR, Nelson. Princípios do processo na constituição federal. $10^{\underline{a}}$ ed. São Paulo: Revista dos Tribunais, 2010.

NETO, Olavo de Oliveira. Princípios informativos da execução civil. In: ALVIM, Arruda et al (coords.). Execução civil e temas afins. São Paulo: Revista dos Tribunais, 2014.

NEVES, Daniel Amorim Assumpção. Manual de direito processual civil. $8^{a}$ ed. Salvador: JusPodivm, 2016.

NEVES, Daniel Amorim Assumpção. Medidas executivas coercitivas atípicas na execução de obrigação de pagar quantia certa - art. 139, IV, do Novo CPC. Revista de processo, São Paulo, v. 265, p. 107-150, mar. 2017. Disponível em: <https://www.revistadostribunais.com.br/maf/app/resultList/document?docguid=la8 1f8de0e50b11e6a673010000000000>. Acesso em: 02 jan. 2018.

OLIVEIRA NETO, Olavo de. A defesa do executado e dos terceiros na execução forçada. São Paulo: Revista dos Tribunais, 2000.

O poder geral de coerção. São Paulo: Thomsom Reuters Brasil, 2019.

. Princípios informativos da execução civil. In: ALVIM, Arruda et al. (coords.). Execução civil e temas afins. São Paulo: Revista dos Tribunais, 2014.

PINHEIRO, Paulo Eduardo D'Arce. Poderes executórios atípicos no projeto de código de processo civil. In: ALVIM, Arruda et al (coords.). Execução civil e temas afins. São Paulo: Revista dos Tribunais, 2014.

Poderes executórios do juiz. São Paulo: Saraiva, 2011.

PULIDO, Carlos Bernal. El principio de proporcionalidad y los derechos fundamentales. 3 ${ }^{\underline{a}}$ ed. Madrid: Centro de Estudios Políticos y Constitucionales, 2007.

PUOLI, José Carlos Baptista. Os poderes do juiz e as reformas do processo civil. São Paulo: Juarez de Oliveira, 2002.

Poderes de efetivação e inconstitucionalidade da parte final do inc. IV do art. 139 do CC/2015. In: AMADEO, Rodolfo da Costa Manso Real et al (coord.). Direito processual civil contemporâneo: estudos em homenagem ao professor Walter Piva Rodrigues. Indaiatuba: Foco, 2019.

RAMOS, Luciana de Oliveira et al. Relatório ICJBrasil - 10 semestre / 2017. Disponível em <http://bibliotecadigital.fgv.br/dspace/bitstream/handle/10438/19034 /Relatorio ICJBrasil_1_sem_2017.pdf >. Acesso em 31 dez. 2019.

REIS, José Alberto dos. Processo de execução. 3ª ed. Coimbra: Coimbra Editora, 1985. v. 1. 
REVISTA CONSULTOR JURÍDICO. Juiz bloqueia $10 \%$ de conta corrente e passaporte. Disponível em: <https://www.conjur.com.br/2018-fev-20/juiz-bloqueia10-conta-corrente-passaporte-devedora>. Acesso em: 06 de junho de 2016.;

REVISTA CONSULTOR JURÍDICO. Juíza determina bloqueio de $\mathrm{CNH}$, passaporte e cartões de inadimplente. Disponível em: <https://www.conjur.com.br/2018-fev-15/juiza-determina-bloqueio-cnh-passaportecartoes-devedor>. Acesso em: 06 de junho de 2018.;

REVISTA CONSULTOR JURÍDICO. Para que réu pague dívida, juíza suspende CNH e confisca passaporte. Disponível em: <https://www.conjur.com.br/2016 set 07/reu pague divida juiza suspende cnh confisca passaporte>. Acesso em: 06 de junho de 2018.;

RODOVALHO, Thiago. O necessário diálogo entre doutrina e jurisprudência na concretização do NCPC, art. 191, inc. IV (atipicidade dos meios executivos). In: TALAMINI, Eduardo; MINAMI, Marcos Youji (coords.). Medidas executivas atípicas. Salvador: JusPodivm, 2018.

RODRIGUES, Marcelo Abelha. O que fazer quando o executado é um "cafajeste"? Apreensão de passaporte? Da carteira de motorista? Disponível em: <https://www.migalhas.com.br/dePeso/16,Ml245946,51045>. Acesso em: 29 mai. 2019.

SANTOS, Moacyr Amaral. Ações cominatórias no direito brasileiro. $5^{a}$ ed. São Paulo: M. Limonad, 1973. v. 2.

. Primeiras linhas de direito processual civil. São Paulo: Saraiva, 1995.

SARLET, Ingo Wolfgang. Dignidade da pessoa humana e direitos fundamentais na Constituição Federal de 1988. $4^{\mathrm{a}}$ ed. Porto Alegre: Livraria do Advogado, 2006.

Direitos fundamentais e direito privado: algumas considerações em torno da vinculação dos particulares aos direitos fundamentais. Porto Alegre: Livraria do Advogado, 2000.

SARMENTO, Daniel. A ponderação de interesses na Constituição Federal. Rio de Janeiro: Lumen Juris, 2000.

Direitos fundamentais e relações privadas. $2^{\underline{a}}$ ed. Rio de Janeiro: Lumen Juris, 2008.

SHIMURA, Sergio Seiji. O princípio da menor gravosidade ao executado. In: BRUSCHI, Gilberto (coord.). Execução civil e cumprimento de sentença. São Paulo: Método, 2007. v. 2.

SICA, Heitor Vitor Mendonça. Cognição do juiz na execução civil. São Paulo: Revista dos Tribunais, 2017.

Notas sobre a efetividade da execução civil. In: ALVIM, Arruda et al

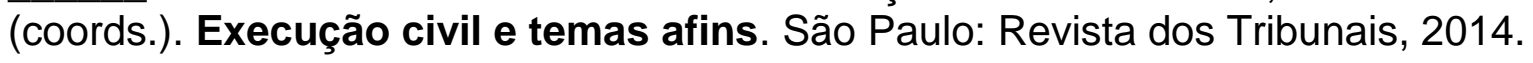


SILVA, Luís Virgílio Afonso da. O proporcional e o razoável. Revista dos tribunais, São Paulo, v. 798, p. 23-50, abr. 2002.

SILVA, Regina Beatriz Tavares da. Bloqueio de cartão de crédito, CNH e passaporte por falta de pagamento da pensão alimentícia. Disponível em: $<$ https://politica.estadao.com.br/blogs/fausto macedo/bloqueio de cartao de credito cnh e passaporte-por-falta-de-pagamento-da-pensao-alimenticia/>. Acesso em: 29 de maio de 2018.

SILVA, Ricardo Alexandre. Atipicidade dos meios executivos na efetivação das decisões que reconheçam o dever de pagar quantia no novo CPC. In: DIDIER JR., Fredie et al (coord.). Novo CPC doutrina selecionada. $1^{\text {a }}$ ed. Salvador: JusPodivm, 2015. v. 5.

SOUSA, Miguel Teixeira de. Acção executiva singular. Lisboa: Lex, 1998.

STEINMETZ, Wilson. A vinculação dos particulares aos direitos fundamentais. São Paulo: Malheiros, 2004.

STRECK, Lenio Luiz; NUNES, Dierle. Como interpretar o artigo 139, IV, do CPC? Carta branca para o arbítrio. Disponível em: <https://www.conjur.com.br/2016ago-25/senso-incomum-interpretar-art-139-iv-cpc-carta-branca-arbitrio>. Acesso em: 29 mai. 2018.

TALAMINI, Eduardo. Medidas coercitivas e proporcionalidade: o caso WhatsApp. In CABRAL, Antonio do Passo. PACELLI, Eugênio. CRUZ, Rogério Schietti (coords.). Processo Penal. Salvador: Juspodivm. 2016.

Poder geral de adoção de medidas executivas e sua incidência nas diferentes modalidades de execução. In: TALAMINI, Eduardo; MINAMI, Marcos Youji (coords.). Medidas executivas atípicas. Salvador: JusPodivm, 2018.

Tutela relativa aos direitos de fazer e de não fazer. São Paulo: Revista dos Tribunais, 2001.

TARUFFO, Michele. A atuação executiva dos direitos: perfis comparados. In: MITIDIERO, Daniel (org.). Processo civil comparado: ensaios. Tradução de Daniel Mitidiero. São Paulo: Marcial Pons, 2013.

A atuação executiva: perfis comparatísticos. Revista de Processo, São

Paulo, v. 59, pgs. 72-97, jul-set 1990. Disponível em: <https://www.revistadostribunais.com.br/maf/app/resultList/document?docguid=149 956bd0f25711dfab6f010000000000 >. Acesso em: 19 jun. 2018.

TEPEDINO, Gustavo. Direitos humanos e relações jurídicas privadas. In: Temas de direito civil. Rio de Janeiro: Renovar, 1999.

THE UNIVERSITY OF CHICAGO. The coercive function of civil contempt. University of Chicago Law Review, 33(1), pgs. 120-133, 1965. Disponível em: $<$ https://heinonline.org/HOL/P?h=hein.journals/uclr33\&i=132>. Acesso em 11 nov. 2019. 
THEODORO JÚNIOR, Humberto. Curso de direito processual civil. $47^{a}$ ed. Rio de Janeiro: Forense, 2016 [livro eletrônico]. v. 3.

Processo de execução e cumprimento de sentença. 24를 ed. São Paulo: Leud, 2007.

TUCCI, José Rogério Cruz e. Ampliação dos poderes do juiz no Novo CPC e princípio da legalidade. Disponível em: <https://www.conjur.com.br/2016-set27/paradoxo-corte-ampliacao-poderes-juiz-cpc-principio-legalidade>. Acesso em: 19 mai. 2018.

UNITED NATIONS. Status of ratification. Disponível em: <https://indicators.ohchr.org/>. Acesso em: 02. dez. 2019.

YARSHELL, Flávio Luiz. Ampliação da responsabilidade patrimonial: caminho para solução da falta de efetividade da execução brasileira? In: ALVIM, Arruda et al (coords.). Execução civil e temas afins. São Paulo: Revista dos Tribunais, 2014.

. Brevíssimas considerações sobre as medidas indutivas e coercitivas nas obrigações de pagamento de quantia. In: LUCON, Paulo Henrique dos Santos. Novos desafios da advocacia e o código de processo civil de 2015: debates de XXIII Conferência Nacional da Advocacia Brasileira. Florianópolis: Empório do Direito, 2018.

ZAVASCKI, Teori Albino. Processo de execução - parte geral. $3^{a}$ ed. São Paulo: Revista dos Tribunais, 2004. 


\section{APÊNDICE}

A presente pesquisa buscou atualizar o levantamento iniciado por Fernando da Fonseca Gajardoni em coautoria com Augusto Martins Pereira ${ }^{531}$ e avançada por Elias Marques de Medeiros Neto em coautoria com Caroline Pastri Pinto Reinas ${ }^{532}$.

A pesquisa realizada por Gajardoni e Pereira analisou acórdãos do Tribunal de Justiça do Estado de São Paulo, no período janeiro a junho de 2017, com recorte metodológico para levar em consideração apenas acórdãos de julgamento de recursos de agravo de instrumento interpostos contra decisões proferidas em execução de título extrajudicial, excluindo cumprimentos de sentença da pesquisa.

Nesse contexto, foi averiguado se a decisão de primeira instância deferiu ou indeferiu ao menos uma das medidas de suspensão do direito de dirigir veículo automotor - ou da carteira nacional de habilitação - , cancelamento e/ou bloqueio de cartões de crédito e a retenção de passaportes, apuradas como sendo as mais comuns medidas atípicas requeridas perante os tribunais brasileiros.

Assim, Gajardoni e Pereira identificaram que as seguintes foram as justificativas mais utilizadas para inferir as medidas restritivas de direito: violação a qualquer dos enunciados do artigo $8^{\circ}$ do CPC/2015, violação ao artigo 5을 inciso XV, da Constituição Federal, violação ao artigo 805 do CPC/2015, inocuidade da medida, violação ao artigo 789 do CPC/2015, ausência de esgotamento das medidas típicas, ausência de relação da medida com o caso concreto, natureza e/ou função punitiva da medida aplicada ou ausência de indícios de ocultação patrimonial.

A pesquisa de Medeiros Neto e Reinas considerou exatamente os mesmos parâmetros, com exceção da análise acerca da relação da medida com o caso concreto. Considerando a exclusão efetuada por Medeiros Neto e Reinas, também não consideramos a relação da medida com o caso concreto no nosso

531 GAJARDONI, Fernando da Fonseca; PEREIRA, Augusto Martins. Medidas atípicas na execução civil: análise de casos no âmbito do TJSP. In: MARCATO, Ana Cândida Menezes et al. Reflexões sobre o código de processo civil de 2015. São Paulo: Verbatim, 2018.

532 MEDEIROS NETO, Elias Marque de; REINAS, Caroline Pastri Pinto. A aplicação das medidas executivas atípicas do artigo 139, inciso IV, do CPC/2015 pelo Tribunal de Justiça do Estado de São Paulo. Revista de Processo, São Paulo, v. 286, p. 277-297, dez. 2018. Disponível em: $<$ https://www.revistadostribunais.com.br/maf/app/resultList/document?\&docguid=Ic2b6c570e24c11 e886f0010000000000>. Acesso em: 05 out. 2019. n.p. 
levantamento, eis que inviabilizado, nesse ponto, o objeto maior da nossa pesquisa, que é, justamente, verificar a evolução do pensamento do Tribunal de Justiça do Estado de São Paulo nesses três anos, de 2017, 2018 e 2019.

Apresentado esse panorama, a nossa análise considerou, para a confecção da Tabela 1, da Tabela 2 e da Tabela 3, que foram divididas dessa forma para melhor visualização dos dados, os seguintes elementos:

Coluna "Recurso": identifica o número do processo relacionado ao recurso analisado no levantamento jurimétrico de acordo com o padrão de numeração do Conselho Nacional de Justiça e que pode ser consultado por qualquer interessado no site https://esaj.tjsp.jus.br/cjsg/consultaCompleta.do.

Coluna "Julgamento": identifica a data de julgamento do recurso relacionado na mesma linha da planilha.

Coluna " $1^{\text {a }}$ Instância": indica se a decisão recorrida proferida pelo juízo de $1^{\text {a }}$ instância deferiu ou indeferiu qualquer das medidas executivas atípicas identificadas nas colunas $\mathrm{CNH}$, Passaporte e Cartão de Crédito.

Coluna "2a Instância": indica se o acórdão analisado, ao final, com a confirmação ou reforma da decisão de $1^{\underline{a}}$ instância, acabou por autorizar ou afastar o emprego de qualquer das medidas executivas atípicas identificadas nas colunas $\mathrm{CNH}$, Passaporte e Cartão de Crédito.

Coluna "CNH": identifica se a ordem de apreensão, suspensão, bloqueio da carteira nacional de habilitação ou qualquer medida equivalente que implique em óbice à condução de veículos automotores sujeitos à regulamentação específica do Código de Trânsito Brasileiro foi objeto do caso analisado.

Coluna "Passaporte": identifica se a ordem de apreensão, suspensão, bloqueio do passaporte ou qualquer medida equivalente que implique em vedação ao livre trânsito para dentro e fora do território brasileiro, condicionado à garantia ou não do débito objeto da execução, foi objeto do caso analisado.

Coluna "Cartão de crédito": identifica se a ordem de apreensão, suspensão, cancelamento ou restrição à utilização de cartões de crédito ou equivalente foi objeto do caso analisado.

Coluna "Art. 80": identifica se as disposições do artigo 8 do CPC/2015, notadamente os princípios da proporcionalidade, razoabilidade, legalidade e eficiência, são causa de decidir no acórdão analisado. 
Coluna "Ir e Vir": identifica se a garantia de ir e vir, a liberdade de locomoção ou o artigo 5º, inciso XV, da Constituição Federal são causa de decidir no acórdão analisado.

Coluna "Onerosidade": identifica se o princípio da menor onerosidade ou o artigo 805 do CPC/2015 são causa de decidir no acórdão analisado.

Coluna "Inocuidade": identifica se a possível inocuidade da medida atípica pleiteada em efetivamente compelir o devedor a efetuar o pagamento do débito ou a ausência de possibilidade de 0 ato judicial pleiteado significar a obtenção ou transformação de outros direitos em valores pecuniários foi causa de decidir no acórdão analisado.

Coluna "Patrimonialidade": identifica se o princípio da patrimonialidade e os artigos 789 e 797 do CPC/2015 são causa de decidir no acórdão analisado.

Coluna "Subsidiariedade": identifica se a subsidiariedade ou a necessidade de esgotamento das medidas típicas é causa de decidir no acórdão analisado.

Coluna "Punição": identifica se a medida executiva atípica pleiteada foi interpretada como sendo meramente punitiva e se esse fundamento, considerando, que as medidas executivas atípicas teriam caráter exclusivamente sancionatório, o que seria vedado na tutela executiva, foi causa de decidir no acórdão analisado.

Coluna "Ocultação": identifica se a ausência de indícios de ocultação patrimonial foi considerada causa de decidir no acórdão analisado.

Adicionalmente, temos, ainda, os seguintes elementos:

Coluna "CNIB": identifica se a ordem de indisponibilidade geral de ativos por meio de cadastro na Central Nacional de Indisponibilidade de Bens foi objeto do caso analisado.

Coluna "Contraditório": identifica se a ausência de garantia de contraditório e ampla defesa foi utilizado como causa de decidir no acórdão analisado.

Coluna "Fundamentação": identifica se vício de fundamentação foi utilizado como causa de decidir no acórdão analisado.

Por fim, destacamos que a pesquisa se baseia em 150 acórdãos no levantamento com inclusão da CNIB como critério de pesquisa e em 132 acórdãos no levantamento com exclusão da CNIB como critério de pesquisa, todos proferidos entre os meses de junho e agosto do ano de 2019. 
Tabela 1. Levantamento da jurisprudência do Tribunal de Justiça do Estado de São Paulo - Dados sobre o resultado do julgamento dos recursos analisados.

Atualização da pesquisa iniciada por Fernando da Fonseca Gajardoni em coautoria com Augusto Martins Pereira ${ }^{533}$ e avançada por Elias Marques de Medeiros Neto em coautoria com Caroline Pastri Pinto Reinas ${ }^{534}$, com critérios adicionais.

\begin{tabular}{|c|c|c|c|}
\hline Recurso & Julgamento & 1a Instância & 2a Instância \\
\hline $2003602-04.2019 .8 .26 .0000$ & $27 / 08 / 2019$ & Indeferiu & Indeferiu \\
\hline $2023416-02.2019 .8 .26 .0000$ & $29 / 08 / 2019$ & Indeferiu & Indeferiu \\
\hline $2029787-79.2019 .8 .26 .0000$ & $10 / 07 / 2019$ & Indeferiu & Indeferiu \\
\hline $2037219-52.2019 .8 .26 .0000$ & $14 / 08 / 2019$ & Indeferiu & Indeferiu \\
\hline $2041181-83.2019 .8 .26 .0000$ & $10 / 07 / 2019$ & Indeferiu & Indeferiu \\
\hline $2043896-98.2019 .8 .26 .0000$ & $13 / 08 / 2019$ & Indeferiu & Indeferiu \\
\hline $2047694-67.2019 .8 .26 .0000$ & $19 / 09 / 2019$ & Indeferiu & Deferiu \\
\hline $2049358-36.2019 .8 .26 .0000$ & $03 / 06 / 2019$ & Indeferiu & Indeferiu \\
\hline $2051214-35.2019 .8 .26 .0000$ & $01 / 07 / 2019$ & Indeferiu & Deferiu \\
\hline $2053017-53.2019 .8 .26 .0000$ & $26 / 06 / 2019$ & Indeferiu & Indeferiu \\
\hline $2053672-25.2019 .8 .26 .0000$ & $28 / 06 / 2019$ & Deferiu & Indeferiu \\
\hline $2053739-87.2019 .8 .26 .0000$ & $03 / 07 / 2019$ & Indeferiu & Indeferiu \\
\hline $2054944-54.2019 .8 .26 .0000$ & $28 / 06 / 2019$ & Indeferiu & Indeferiu \\
\hline $2057030-95.2019 .8 .26 .0000$ & $24 / 06 / 2019$ & Deferiu & Indeferiu \\
\hline $2060589-60.2019 .8 .26 .0000$ & $03 / 07 / 2019$ & Indeferiu & Deferiu \\
\hline $2062370-20.2019 .8 .26 .0000$ & $28 / 06 / 2019$ & Indeferiu & Indeferiu \\
\hline $2068735-90.2019 .8 .26 .0000$ & $06 / 06 / 2019$ & Deferiu & Indeferiu \\
\hline $2070292-15.2019 .8 .26 .0000$ & $21 / 08 / 2019$ & Indeferiu & Deferiu \\
\hline $2071483-95.2019 .8 .26 .0000$ & $06 / 06 / 2019$ & Indeferiu & Indeferiu \\
\hline $2071709-03.2019 .8 .26 .0000$ & $10 / 06 / 2019$ & Indeferiu & Deferiu \\
\hline $2072883-47.2019 .8 .26 .0000$ & $14 / 06 / 2019$ & Indeferiu & Deferiu \\
\hline $2075351-81.2019 .8 .26 .0000$ & $11 / 06 / 2019$ & Indeferiu & Indeferiu \\
\hline $2075552-73.2019 .8 .26 .0000$ & $15 / 07 / 2019$ & Indeferiu & Deferiu \\
\hline $2082145-21.2019 .8 .26 .0000$ & $12 / 07 / 2019$ & Indeferiu & Indeferiu \\
\hline $2082164-27.2019 .8 .26 .0000$ & $05 / 07 / 2019$ & Indeferiu & Indeferiu \\
\hline $2082569-63.2019 .8 .26 .0000$ & $07 / 08 / 2019$ & Deferiu & Indeferiu \\
\hline
\end{tabular}

533 GAJARDONI, Fernando da Fonseca; PEREIRA, Augusto Martins. Medidas atípicas na execução civil: análise de casos no âmbito do TJSP. In: MARCATO, Ana Cândida Menezes et al. Reflexões sobre o código de processo civil de 2015. São Paulo: Verbatim, 2018.

534 MEDEIROS NETO, Elias Marque de; REINAS, Caroline Pastri Pinto. A aplicação das medidas executivas atípicas do artigo 139, inciso IV, do CPC/2015 pelo Tribunal de Justiça do Estado de São Paulo. Revista de Processo, São Paulo, v. 286, p. 277-297, dez. 2018. Disponível em: $<$ https://www.revistadostribunais.com.br/maf/app/resultList/document?\&docguid=Ic2b6c570e24c11 e886f0010000000000 >. Acesso em: 05 out. 2019. n.p. 


\begin{tabular}{|c|c|c|c|}
\hline Recurso & Julgamento & 1a Instância & 2a Instância \\
\hline 2083263-32.2019.8.26.0000 & $10 / 07 / 2019$ & Indeferiu & Indeferiu \\
\hline 2084471-51.2019.8.26.0000 & 05/06/2019 & Indeferiu & Indeferiu \\
\hline 2084933-08.2019.8.26.0000 & $28 / 06 / 2019$ & Indeferiu & Indeferiu \\
\hline 2085018-91.2019.8.26.0000 & $26 / 06 / 2019$ & Deferiu & Indeferiu \\
\hline 2086569-09.2019.8.26.0000 & $03 / 07 / 2019$ & Indeferiu & Indeferiu \\
\hline 2087169-30.2019.8.26.0000 & $22 / 08 / 2019$ & Deferiu & Deferiu \\
\hline 2090034-26.2019.8.26.0000 & $19 / 06 / 2019$ & Deferiu & Indeferiu \\
\hline 2091597-55.2019.8.26.0000 & $28 / 06 / 2019$ & Indeferiu & Deferiu \\
\hline 2091917-08.2019.8.26.0000 & $26 / 06 / 2019$ & Indeferiu & Deferiu \\
\hline 2091941-36.2019.8.26.0000 & 03/06/2019 & Deferiu & Indeferiu \\
\hline 2093392-96.2019.8.26.0000 & $16 / 07 / 2019$ & Indeferiu & Indeferiu \\
\hline $2093760-08.2019 .8 .26 .0000$ & $05 / 07 / 2019$ & Indeferiu & Indeferiu \\
\hline $2095225-52.2019 .8 .26 .0000$ & $17 / 06 / 2019$ & Deferiu & Indeferiu \\
\hline 2097817-69.2019.8.26.0000 & $17 / 07 / 2019$ & Indeferiu & Deferiu \\
\hline 2098379-78.2019.8.26.0000 & $28 / 06 / 2019$ & Indeferiu & Indeferiu \\
\hline 2099490-97.2019.8.26.0000 & $05 / 08 / 2019$ & Indeferiu & Deferiu \\
\hline 2101643-06.2019.8.26.0000 & $10 / 06 / 2019$ & Indeferiu & Indeferiu \\
\hline $2101726-22.2019 .8 .26 .0000$ & $23 / 07 / 2019$ & Deferiu & Indeferiu \\
\hline $2103856-82.2019 .8 .26 .0000$ & $27 / 06 / 2019$ & Indeferiu & Deferiu \\
\hline $2103896-64.2019 .8 .26 .0000$ & $06 / 06 / 2019$ & Deferiu & Indeferiu \\
\hline $2107030-02.2019 .8 .26 .0000$ & $28 / 06 / 2019$ & Indeferiu & Indeferiu \\
\hline 2109234-19.2019.8.26.0000 & $11 / 07 / 2019$ & Deferiu & Indeferiu \\
\hline 2111953-71.2019.8.26.0000 & $31 / 07 / 2019$ & Indeferiu & Deferiu \\
\hline 2112423-05.2019.8.26.0000 & $10 / 06 / 2019$ & Indeferiu & Indeferiu \\
\hline $2112676-90.2019 .8 .26 .0000$ & $29 / 06 / 2019$ & Indeferiu & Indeferiu \\
\hline 2113645-08.2019.8.26.0000 & $16 / 07 / 2019$ & Deferiu & Indeferiu \\
\hline 2114275-64.2019.8.26.0000 & 06/08/2019 & Deferiu & Indeferiu \\
\hline $2114302-47.2019 .8 .26 .0000$ & 05/08/2019 & Deferiu & Indeferiu \\
\hline 2114659-27.2019.8.26.0000 & $01 / 08 / 2019$ & Deferiu & Deferiu \\
\hline 2116374-07.2019.8.26.0000 & $04 / 07 / 2019$ & Indeferiu & Indeferiu \\
\hline $2116685-95.2019 .8 .26 .0000$ & $24 / 06 / 2019$ & Indeferiu & Indeferiu \\
\hline 2116820-10.2019.8.26.0000 & $31 / 07 / 2019$ & Deferiu & Indeferiu \\
\hline $2117044-45.2019 .8 .26 .0000$ & $17 / 07 / 2019$ & Indeferiu & Indeferiu \\
\hline $2118032-66.2019 .8 .26 .0000$ & $14 / 06 / 2019$ & Indeferiu & Deferiu \\
\hline 2118071-63.2019.8.26.0000 & $01 / 07 / 2019$ & Indeferiu & Indeferiu \\
\hline 2118471-77.2019.8.26.0000 & $16 / 07 / 2019$ & Deferiu & Indeferiu \\
\hline $2119006-06.2019 .8 .26 .0000$ & $26 / 07 / 2019$ & Indeferiu & Indeferiu \\
\hline 2119815-93.2019.8.26.0000 & $23 / 07 / 2019$ & Indeferiu & Indeferiu \\
\hline $2120340-75.2019 .8 .26 .0000$ & $02 / 07 / 2019$ & Indeferiu & Deferiu \\
\hline $2120812-76.2019 .8 .26 .0000$ & $01 / 07 / 2019$ & Indeferiu & Indeferiu \\
\hline $2121476-10.2019 .8 .26 .0000$ & $20 / 08 / 2019$ & Deferiu & Indeferiu \\
\hline $2121579-17.2019 .8 .26 .0000$ & $10 / 06 / 2019$ & Indeferiu & Indeferiu \\
\hline 2121972-39.2019.8.26.0000 & $26 / 06 / 2019$ & Indeferiu & Deferiu \\
\hline 2122179-38.2019.8.26.0000 & $12 / 08 / 2019$ & Indeferiu & Indeferiu \\
\hline
\end{tabular}




\begin{tabular}{|c|c|c|c|}
\hline Recurso & Julgamento & 1a Instância & 2a Instância \\
\hline 2122199-29.2019.8.26.0000 & $07 / 08 / 2019$ & Deferiu & Deferiu \\
\hline 2122677-37.2019.8.26.0000 & 06/08/2019 & Indeferiu & Indeferiu \\
\hline 2123167-59.2019.8.26.0000 & $27 / 06 / 2019$ & Indeferiu & Indeferiu \\
\hline $2123852-66.2019 .8 .26 .0000$ & $25 / 06 / 2019$ & Indeferiu & Deferiu \\
\hline 2124021-53.2019.8.26.0000 & $15 / 08 / 2019$ & Indeferiu & Indeferiu \\
\hline $2124034-52.2019 .8 .26 .0000$ & $23 / 07 / 2019$ & Deferiu & Indeferiu \\
\hline $2124138-44.2019 .8 .26 .0000$ & $12 / 08 / 2019$ & Deferiu & Indeferiu \\
\hline $2124405-16.2019 .8 .26 .0000$ & $20 / 08 / 2019$ & Deferiu & Indeferiu \\
\hline 2125022-73.2019.8.26.0000 & $30 / 07 / 2019$ & Indeferiu & Indeferiu \\
\hline $2125748-47.2019 .8 .26 .0000$ & $08 / 08 / 2019$ & Deferiu & Indeferiu \\
\hline 2125795-21.2019.8.26.0000 & $24 / 06 / 2019$ & Indeferiu & Indeferiu \\
\hline $2125950-24.2019 .8 .26 .0000$ & $18 / 06 / 2019$ & Indeferiu & Indeferiu \\
\hline $2126098-35.2019 .8 .26 .0000$ & $28 / 08 / 2019$ & Indeferiu & Indeferiu \\
\hline $2126135-62.2019 .8 .26 .0000$ & $27 / 08 / 2019$ & Indeferiu & Indeferiu \\
\hline $2126286-28.2019 .8 .26 .0000$ & $09 / 08 / 2019$ & Indeferiu & Indeferiu \\
\hline $2126435-24.2019 .8 .26 .0000$ & $25 / 07 / 2019$ & Indeferiu & Indeferiu \\
\hline $2126484-65.2019 .8 .26 .0000$ & $22 / 07 / 2019$ & Indeferiu & Indeferiu \\
\hline $2127430-37.2019 .8 .26 .0000$ & $09 / 08 / 2019$ & Indeferiu & Indeferiu \\
\hline 2128509-51.2019.8.26.0000 & $28 / 08 / 2019$ & Indeferiu & Indeferiu \\
\hline $2129640-61.2019 .8 .26 .0000$ & $04 / 07 / 2019$ & Indeferiu & Indeferiu \\
\hline 2129719-40.2019.8.26.0000 & $08 / 08 / 2019$ & Indeferiu & Indeferiu \\
\hline $2129894-34.2019 .8 .26 .0000$ & $25 / 07 / 2019$ & Indeferiu & Deferiu \\
\hline 2130599-32.2019.8.26.0000 & $15 / 07 / 2019$ & Indeferiu & Indeferiu \\
\hline $2131338-05.2019 .8 .26 .0000$ & 05/07/2019 & Indeferiu & Indeferiu \\
\hline 2131362-33.2019.8.26.0000 & $29 / 08 / 2019$ & Indeferiu & Deferiu \\
\hline 2131942-63.2019.8.26.0000 & $24 / 06 / 2019$ & Indeferiu & Indeferiu \\
\hline 2133674-79.2019.8.26.0000 & $31 / 07 / 2019$ & Indeferiu & Indeferiu \\
\hline 2135712-64.2019.8.26.0000 & $14 / 08 / 2019$ & Deferiu & Indeferiu \\
\hline 2136151-75.2019.8.26.0000 & $05 / 08 / 2019$ & Indeferiu & Indeferiu \\
\hline $2136505-03.2019 .8 .26 .0000$ & $31 / 07 / 2019$ & Indeferiu & Indeferiu \\
\hline $2138305-66.2019 .8 .26 .0000$ & $27 / 08 / 2019$ & Indeferiu & Indeferiu \\
\hline 2138307-36.2019.8.26.0000 & $28 / 08 / 2019$ & Deferiu & Indeferiu \\
\hline 2138552-47.2019.8.26.0000 & $21 / 08 / 2019$ & Deferiu & Indeferiu \\
\hline $2139429-84.2019 .8 .26 .0000$ & $09 / 08 / 2019$ & Indeferiu & Indeferiu \\
\hline 2140281-11.2019.8.26.0000 & $12 / 08 / 2019$ & Indeferiu & Indeferiu \\
\hline 2140402-39.2019.8.26.0000 & $31 / 07 / 2019$ & Deferiu & Indeferiu \\
\hline $2140515-90.2019 .8 .26 .0000$ & $18 / 07 / 2019$ & Indeferiu & Indeferiu \\
\hline 2140898-68.2019.8.26.0000 & $05 / 07 / 2019$ & Indeferiu & Indeferiu \\
\hline 2142673-21.2019.8.26.0000 & $12 / 08 / 2019$ & Indeferiu & Indeferiu \\
\hline $2142975-50.2019 .8 .26 .0000$ & $20 / 08 / 2019$ & Indeferiu & Indeferiu \\
\hline $2143846-80.2019 .8 .26 .0000$ & $27 / 08 / 2019$ & Indeferiu & Indeferiu \\
\hline $2147629-80.2019 .8 .26 .0000$ & $24 / 07 / 2019$ & Indeferiu & Indeferiu \\
\hline $2148404-95.2019 .8 .26 .0000$ & $28 / 08 / 2019$ & Indeferiu & Indeferiu \\
\hline 2148638-77.2019.8.26.0000 & $27 / 08 / 2019$ & Indeferiu & Indeferiu \\
\hline
\end{tabular}




\begin{tabular}{|c|c|c|c|}
\hline Recurso & Julgamento & 1a Instância & 2a Instância \\
\hline $2148908-04.2019 .8 .26 .0000$ & $08 / 08 / 2019$ & Indeferiu & Indeferiu \\
\hline $2150272-11.2019 .8 .26 .0000$ & $12 / 08 / 2019$ & Indeferiu & Deferiu \\
\hline $2150454-94.2019 .8 .26 .0000$ & $28 / 08 / 2019$ & Indeferiu & Deferiu \\
\hline $2152132-47.2019 .8 .26 .0000$ & $30 / 08 / 2019$ & Indeferiu & Indeferiu \\
\hline $2152635-68.2019 .8 .26 .0000$ & $13 / 08 / 2019$ & Indeferiu & Deferiu \\
\hline $2153609-08.2019 .8 .26 .0000$ & $28 / 08 / 2019$ & Indeferiu & Indeferiu \\
\hline $2154141-79.2019 .8 .26 .0000$ & 09/08/2019 & Indeferiu & Indeferiu \\
\hline $2154152-11.2019 .8 .26 .0000$ & $27 / 08 / 2019$ & Indeferiu & indeferiu \\
\hline 2155889-49.2019.8.26.0000 & $23 / 08 / 2019$ & Indeferiu & Indeferiu \\
\hline 2156407-39.2019.8.26.0000 & $16 / 08 / 2019$ & Indeferiu & Indeferiu \\
\hline $2157409-44.2019 .8 .26 .0000$ & $26 / 08 / 2019$ & Indeferiu & Indeferiu \\
\hline $2157460-55.2019 .8 .26 .0000$ & $16 / 08 / 2019$ & indeferiu & Indeferiu \\
\hline $2157734-19.2019 .8 .26 .0000$ & $22 / 08 / 2019$ & Indeferiu & Indeferiu \\
\hline $2158708-56.2019 .8 .26 .0000$ & $22 / 08 / 2019$ & Indeferiu & Indeferiu \\
\hline 2164534-63.2019.8.26.0000 & $23 / 08 / 2019$ & Indeferiu & Indeferiu \\
\hline $2166719-74.2019 .8 .26 .0000$ & $27 / 08 / 2019$ & Indeferiu & Indeferiu \\
\hline $2167088-68.2019 .8 .26 .0000$ & $22 / 08 / 2019$ & Indeferiu & Indeferiu \\
\hline $2167229-87.2019 .8 .26 .0000$ & $19 / 08 / 2019$ & Indeferiu & Indeferiu \\
\hline $2169254-73.2019 .8 .26 .0000$ & $12 / 08 / 2019$ & Indeferiu & Indeferiu \\
\hline $2169337-89.2019 .8 .26 .0000$ & $20 / 08 / 2019$ & Deferiu & Deferiu \\
\hline 2176161-64.2019.8.26.0000 & $29 / 08 / 2019$ & Indeferiu & Indeferiu \\
\hline $2177530-30.2018 .8 .26 .0000$ & $21 / 08 / 2019$ & Indeferiu & Indeferiu \\
\hline $2178308-63.2019 .8 .26 .0000$ & $29 / 08 / 2019$ & Indeferiu & Indeferiu \\
\hline $2182920-44.2019 .8 .26 .0000$ & $30 / 08 / 2019$ & Indeferiu & Indeferiu \\
\hline $2199332-84.2018 .8 .26 .0000$ & 05/08/2019 & Indeferiu & Indeferiu \\
\hline $2223217-30.2018 .8 .26 .0000$ & $05 / 06 / 2019$ & Indeferiu & Indeferiu \\
\hline $2233578-09.2018 .8 .26 .0000$ & $20 / 08 / 2019$ & Indeferiu & Indeferiu \\
\hline $2238929-60.2018 .8 .26 .0000$ & $01 / 07 / 2019$ & Indeferiu & Indeferiu \\
\hline $2247367-75.2018 .8 .26 .0000$ & $24 / 06 / 2019$ & Indeferiu & Indeferiu \\
\hline $2248190-49.2018 .8 .26 .0000$ & $05 / 06 / 2019$ & Indeferiu & Deferiu \\
\hline $2250396-36.2018 .8 .26 .0000$ & $05 / 08 / 2019$ & Indeferiu & Indeferiu \\
\hline $2257231-40.2018 .8 .26 .0000$ & $19 / 08 / 2019$ & Deferiu & Indeferiu \\
\hline $2261837-14.2018 .8 .26 .0000$ & $03 / 06 / 2019$ & Indeferiu & Indeferiu \\
\hline $2266747-84.2018 .8 .26 .0000$ & $04 / 07 / 2019$ & Indeferiu & Indeferiu \\
\hline $2269880-37.2018 .8 .26 .0000$ & $21 / 08 / 2019$ & Indeferiu & Indeferiu \\
\hline $2275384-24.2018 .8 .26 .0000$ & $19 / 06 / 2019$ & Indeferiu & Indeferiu \\
\hline
\end{tabular}


Tabela 2. Levantamento da jurisprudência do Tribunal de Justiça do Estado de São Paulo - Dados sobre o deferimento ou não das medidas
coercitivas atípicas mais comuns.

Atualização da pesquisa iniciada por Fernando da Fonseca Gajardoni em coautoria com Augusto Martins Pereira ${ }^{535}$ e avançada por Elias Marques de Medeiros Neto em coautoria com Caroline Pastri Pinto Reinas ${ }^{536}$, com critérios adicionais.

\begin{tabular}{|c|c|c|c|c|}
\hline Recurso & $\mathrm{CNH}$ & Passaporte & Cartão de crédito & CNIB \\
\hline 2003602-04.2019.8.26.0000 & Não & Não & Sim & Não \\
\hline 2023416-02.2019.8.26.0000 & Sim & Sim & Não & Não \\
\hline 2029787-79.2019.8.26.0000 & Sim & Sim & Não & Não \\
\hline 2037219-52.2019.8.26.0000 & Sim & Sim & Sim & Não \\
\hline 2041181-83.2019.8.26.0000 & Sim & Não & Não & Não \\
\hline 2043896-98.2019.8.26.0000 & Sim & Sim & Sim & Não \\
\hline 2047694-67.2019.8.26.0000 & Não & Não & Não & Sim \\
\hline $2049358-36.2019 .8 .26 .0000$ & Sim & Sim & Sim & Não \\
\hline 2051214-35.2019.8.26.0000 & Não & Não & Não & Sim \\
\hline 2053017-53.2019.8.26.0000 & Sim & Não & Não & Não \\
\hline $2053672-25.2019 .8 .26 .0000$ & Sim & Não & Não & Não \\
\hline 2053739-87.2019.8.26.0000 & Sim & Sim & Sim & Não \\
\hline 2054944-54.2019.8.26.0000 & Sim & Não & Não & Não \\
\hline $2057030-95.2019 .8 .26 .0000$ & Sim & Não & Sim & Não \\
\hline 2060589-60.2019.8.26.0000 & Não & Não & Não & Sim \\
\hline 2062370-20.2019.8.26.0000 & Não & Sim & Não & Não \\
\hline $2068735-90.2019 .8 .26 .0000$ & Não & Não & Não & Não \\
\hline 2070292-15.2019.8.26.0000 & Não & Não & Não & Sim \\
\hline 2071483-95.2019.8.26.0000 & Sim & Não & Sim & Não \\
\hline 2071709-03.2019.8.26.0000 & Não & Não & Não & Sim \\
\hline 2072883-47.2019.8.26.0000 & Sim & Não & Não & Não \\
\hline 2075351-81.2019.8.26.0000 & Sim & Sim & Não & Não \\
\hline $2075552-73.2019 .8 .26 .0000$ & Não & Não & Não & Sim \\
\hline 2082145-21.2019.8.26.0000 & Sim & Sim & Sim & Não \\
\hline 2082164-27.2019.8.26.0000 & Sim & Sim & Sim & Não \\
\hline $2082569-63.2019 .8 .26 .0000$ & Sim & Sim & Sim & Não \\
\hline
\end{tabular}

535 GAJARDONI, Fernando da Fonseca; PEREIRA, Augusto Martins. Medidas atípicas na execução civil: análise de casos no âmbito do TJSP. In: MARCATO, Ana Cândida Menezes et al. Reflexões sobre o código de processo civil de 2015. São Paulo: Verbatim, 2018.

536 MEDEIROS NETO, Elias Marque de; REINAS, Caroline Pastri Pinto. A aplicação das medidas executivas atípicas do artigo 139, inciso IV, do CPC/2015 pelo Tribunal de Justiça do Estado de São Paulo. Revista de Processo, São Paulo, v. 286, p. 277-297, dez. 2018. Disponível em: $<$ https://www.revistadostribunais.com.br/maf/app/resultList/document?\&docguid=Ic2b6c570e24c11 e886f0010000000000>. Acesso em: 05 out. 2019. n.p. 


\begin{tabular}{|c|c|c|c|c|}
\hline Recurso & CNH & Passaporte & Cartão de crédito & CNIB \\
\hline 2083263-32.2019.8.26.0000 & Sim & Sim & Sim & Não \\
\hline 2084471-51.2019.8.26.0000 & Sim & Não & Não & Não \\
\hline 2084933-08.2019.8.26.0000 & Sim & Sim & Sim & Não \\
\hline 2085018-91.2019.8.26.0000 & Sim & Sim & Não & Não \\
\hline 2086569-09.2019.8.26.0000 & Sim & Sim & Sim & Não \\
\hline 2087169-30.2019.8.26.0000 & Não & Sim & Não & Não \\
\hline 2090034-26.2019.8.26.0000 & Sim & Não & Não & Não \\
\hline 2091597-55.2019.8.26.0000 & Sim & Sim & Sim & Não \\
\hline 2091917-08.2019.8.26.0000 & Não & Não & Não & Sim \\
\hline 2091941-36.2019.8.26.0000 & Sim & Sim & Sim & Não \\
\hline 2093392-96.2019.8.26.0000 & Sim & Sim & Sim & Não \\
\hline 2093760-08.2019.8.26.0000 & Sim & Sim & Sim & Não \\
\hline 2095225-52.2019.8.26.0000 & Sim & Não & Não & Não \\
\hline 2097817-69.2019.8.26.0000 & Não & Não & Não & Sim \\
\hline 2098379-78.2019.8.26.0000 & Sim & Sim & Sim & Não \\
\hline 2099490-97.2019.8.26.0000 & Não & Não & Não & Sim \\
\hline 2101643-06.2019.8.26.0000 & Sim & Sim & Não & Não \\
\hline 2101726-22.2019.8.26.0000 & Sim & Sim & Sim & Não \\
\hline $2103856-82.2019 .8 .26 .0000$ & Sim & Sim & Sim & Não \\
\hline $2103896-64.2019 .8 .26 .0000$ & Sim & Sim & Sim & Não \\
\hline 2107030-02.2019.8.26.0000 & Não & Não & Sim & Não \\
\hline 2109234-19.2019.8.26.0000 & Sim & Sim & Não & Não \\
\hline 2111953-71.2019.8.26.0000 & Não & Não & Não & Sim \\
\hline 2112423-05.2019.8.26.0000 & Sim & Sim & Sim & Não \\
\hline 2112676-90.2019.8.26.0000 & Sim & Sim & Sim & Não \\
\hline 2113645-08.2019.8.26.0000 & Sim & Sim & Não & Não \\
\hline 2114275-64.2019.8.26.0000 & Sim & Não & Não & Não \\
\hline 2114302-47.2019.8.26.0000 & Sim & Não & Não & Não \\
\hline 2114659-27.2019.8.26.0000 & Sim & Não & Não & Não \\
\hline 2116374-07.2019.8.26.0000 & Não & Sim & Sim & Não \\
\hline 2116685-95.2019.8.26.0000 & Sim & Sim & Sim & Não \\
\hline $2116820-10.2019 .8 .26 .0000$ & Sim & Não & Sim & Não \\
\hline 2117044-45.2019.8.26.0000 & Sim & Sim & Sim & Não \\
\hline 2118032-66.2019.8.26.0000 & Sim & Não & Sim & Não \\
\hline 2118071-63.2019.8.26.0000 & Sim & Sim & Sim & Não \\
\hline 2118471-77.2019.8.26.0000 & Não & Sim & Não & Não \\
\hline 2119006-06.2019.8.26.0000 & Sim & Sim & Sim & Não \\
\hline 2119815-93.2019.8.26.0000 & Sim & Sim & Sim & Não \\
\hline 2120340-75.2019.8.26.0000 & Sim & Sim & Sim & Não \\
\hline 2120812-76.2019.8.26.0000 & Não & Não & Sim & Não \\
\hline 2121476-10.2019.8.26.0000 & Não & Sim & Não & Não \\
\hline 2121579-17.2019.8.26.0000 & Sim & Sim & Não & Não \\
\hline 2121972-39.2019.8.26.0000 & Sim & Sim & $\operatorname{Sim}$ & Não \\
\hline 2122179-38.2019.8.26.0000 & Sim & Sim & Sim & Não \\
\hline
\end{tabular}




\begin{tabular}{|c|c|c|c|c|}
\hline Recurso & $\mathrm{CNH}$ & Passaporte & Cartão de crédito & CNIB \\
\hline 2122199-29.2019.8.26.0000 & Sim & Não & Não & Não \\
\hline 2122677-37.2019.8.26.0000 & Sim & Sim & Não & Não \\
\hline 2123167-59.2019.8.26.0000 & Sim & Sim & Sim & Não \\
\hline 2123852-66.2019.8.26.0000 & Não & Não & Não & Sim \\
\hline 2124021-53.2019.8.26.0000 & Sim & Não & Sim & Não \\
\hline 2124034-52.2019.8.26.0000 & Sim & Não & Não & Não \\
\hline 2124138-44.2019.8.26.0000 & Não & Sim & Não & Não \\
\hline $2124405-16.2019 .8 .26 .0000$ & Não & Sim & Não & Não \\
\hline $2125022-73.2019 .8 .26 .0000$ & Sim & Sim & Sim & Não \\
\hline $2125748-47.2019 .8 .26 .0000$ & Sim & Não & Não & Não \\
\hline 2125795-21.2019.8.26.0000 & Sim & Sim & Sim & Não \\
\hline $2125950-24.2019 .8 .26 .0000$ & Sim & Não & Não & Não \\
\hline $2126098-35.2019 .8 .26 .0000$ & Não & Não & Sim & Não \\
\hline $2126135-62.2019 .8 .26 .0000$ & Sim & Sim & Não & Não \\
\hline $2126286-28.2019 .8 .26 .0000$ & Sim & Sim & Sim & Não \\
\hline $2126435-24.2019 .8 .26 .0000$ & Sim & Sim & Não & Não \\
\hline 2126484-65.2019.8.26.0000 & Sim & Sim & Não & Não \\
\hline $2127430-37.2019 .8 .26 .0000$ & Sim & Não & Sim & Não \\
\hline 2128509-51.2019.8.26.0000 & Sim & Sim & Sim & Não \\
\hline $2129640-61.2019 .8 .26 .0000$ & Sim & Sim & Sim & Não \\
\hline 2129719-40.2019.8.26.0000 & Não & Não & Não & Sim \\
\hline 2129894-34.2019.8.26.0000 & Não & Não & Não & Sim \\
\hline 2130599-32.2019.8.26.0000 & Sim & Não & Sim & Não \\
\hline 2131338-05.2019.8.26.0000 & Não & Não & Não & Sim \\
\hline 2131362-33.2019.8.26.0000 & Sim & Sim & Sim & Não \\
\hline 2131942-63.2019.8.26.0000 & Sim & Não & Não & Não \\
\hline 2133674-79.2019.8.26.0000 & Sim & Sim & Sim & Não \\
\hline 2135712-64.2019.8.26.0000 & Não & Não & Sim & Não \\
\hline 2136151-75.2019.8.26.0000 & Sim & Não & Não & Não \\
\hline $2136505-03.2019 .8 .26 .0000$ & Sim & Não & Sim & Não \\
\hline 2138305-66.2019.8.26.0000 & Sim & Não & Não & Não \\
\hline 2138307-36.2019.8.26.0000 & Sim & Sim & Não & Não \\
\hline $2138552-47.2019 .8 .26 .0000$ & Sim & Não & Não & Sim \\
\hline 2139429-84.2019.8.26.0000 & Sim & Sim & Sim & Não \\
\hline 2140281-11.2019.8.26.0000 & Sim & Sim & Sim & Não \\
\hline 2140402-39.2019.8.26.0000 & Sim & Não & Não & Não \\
\hline $2140515-90.2019 .8 .26 .0000$ & Sim & Não & Não & Não \\
\hline 2140898-68.2019.8.26.0000 & Sim & Sim & Sim & Não \\
\hline 2142673-21.2019.8.26.0000 & Sim & Não & Não & Não \\
\hline $2142975-50.2019 .8 .26 .0000$ & Sim & Sim & Não & Não \\
\hline $2143846-80.2019 .8 .26 .0000$ & Sim & Não & Sim & Não \\
\hline 2147629-80.2019.8.26.0000 & Sim & Não & Sim & Não \\
\hline 2148404-95.2019.8.26.0000 & Sim & Sim & Sim & Não \\
\hline 2148638-77.2019.8.26.0000 & Sim & Sim & Sim & Não \\
\hline
\end{tabular}




\begin{tabular}{|c|c|c|c|c|}
\hline Recurso & $\mathrm{CNH}$ & Passaporte & Cartão de crédito & CNIB \\
\hline 2148908-04.2019.8.26.0000 & Não & Não & Não & Sim \\
\hline 2150272-11.2019.8.26.0000 & Não & Não & Não & Sim \\
\hline 2150454-94.2019.8.26.0000 & Não & Não & Não & Sim \\
\hline 2152132-47.2019.8.26.0000 & Sim & Não & Sim & Não \\
\hline 2152635-68.2019.8.26.0000 & Não & Não & Não & Sim \\
\hline 2153609-08.2019.8.26.0000 & Sim & Sim & Sim & Não \\
\hline 2154141-79.2019.8.26.0000 & Sim & Não & Sim & Não \\
\hline 2154152-11.2019.8.26.0000 & Não & Não & Não & Não \\
\hline 2155889-49.2019.8.26.0000 & Não & Sim & Sim & Não \\
\hline 2156407-39.2019.8.26.0000 & Sim & Sim & Sim & Não \\
\hline 2157409-44.2019.8.26.0000 & Sim & Sim & Sim & Não \\
\hline $2157460-55.2019 .8 .26 .0000$ & Sim & Sim & Sim & Não \\
\hline 2157734-19.2019.8.26.0000 & Sim & Não & Sim & Não \\
\hline 2158708-56.2019.8.26.0000 & Sim & Sim & Sim & Não \\
\hline 2164534-63.2019.8.26.0000 & Sim & Sim & Sim & Não \\
\hline 2166719-74.2019.8.26.0000 & Sim & Não & Sim & Não \\
\hline 2167088-68.2019.8.26.0000 & Sim & Sim & Sim & Não \\
\hline $2167229-87.2019 .8 .26 .0000$ & Sim & Não & Sim & Não \\
\hline 2169254-73.2019.8.26.0000 & Sim & Não & Não & Não \\
\hline 2169337-89.2019.8.26.0000 & Não & Não & Sim & Não \\
\hline 2176161-64.2019.8.26.0000 & Sim & Não & Sim & Não \\
\hline 2177530-30.2018.8.26.0000 & Sim & Sim & Não & Não \\
\hline $2178308-63.2019 .8 .26 .0000$ & Não & Não & Não & Não \\
\hline 2182920-44.2019.8.26.0000 & Sim & Não & Sim & Não \\
\hline 2199332-84.2018.8.26.0000 & Sim & Não & Não & Não \\
\hline $2223217-30.2018 .8 .26 .0000$ & Sim & Sim & Sim & Não \\
\hline $2233578-09.2018 .8 .26 .0000$ & Sim & Sim & Sim & Não \\
\hline 2238929-60.2018.8.26.0000 & Sim & Não & Não & Não \\
\hline $2247367-75.2018 .8 .26 .0000$ & Sim & Sim & Sim & Não \\
\hline $2248190-49.2018 .8 .26 .0000$ & Sim & Não & Não & Sim \\
\hline $2250396-36.2018 .8 .26 .0000$ & Sim & Sim & Sim & Não \\
\hline 2257231-40.2018.8.26.0000 & Sim & Sim & Sim & Não \\
\hline 2261837-14.2018.8.26.0000 & Sim & Sim & Não & Não \\
\hline 2266747-84.2018.8.26.0000 & Sim & Não & Não & Não \\
\hline $2269880-37.2018 .8 .26 .0000$ & Sim & Sim & Sim & Não \\
\hline 2275384-24.2018.8.26.0000 & Sim & Sim & Sim & Não \\
\hline
\end{tabular}


Tabela 3. Levantamento da jurisprudência do Tribunal de Justiça do Estado de São Paulo - Dados sobre as causas mais comuns para o indeferimento das medidas coercitivas atípicas.

Atualização da pesquisa iniciada por Fernando da Fonseca Gajardoni em coautoria com Augusto Martins Pereira ${ }^{537}$ e avançada por Elias Marques de Medeiros Neto em coautoria com Caroline Pastri Pinto Reinas ${ }^{538}$, com critérios adicionais.

\begin{tabular}{|c|c|c|c|c|c|c|c|c|c|c|}
\hline Recurso & Art. 8 - & Ir e Vir & Onerosidade & Inocuidade & Patrimonialidade & Subsidiariedade & Punição & Ocultação & Contraditório & Fundamentação \\
\hline 2003602-04.2019.8.26.0000 & Sim & Não & Sim & Não & Não & Não & Sim & Não & Não & Não \\
\hline 2023416-02.2019.8.26.0000 & Sim & Não & Sim & Sim & Não & Não & Sim & Não & Não & Não \\
\hline 2029787-79.2019.8.26.0000 & Sim & Não & Sim & Sim & Não & Não & Não & Não & Não & Não \\
\hline 2037219-52.2019.8.26.0000 & Sim & Não & Não & Sim & Não & Não & Sim & Não & Não & Não \\
\hline 2041181-83.2019.8.26.0000 & Sim & Não & Sim & Sim & Não & Não & Não & Não & Não & Não \\
\hline 2043896-98.2019.8.26.0000 & Sim & Não & Não & Sim & Não & Não & Não & Não & Não & Não \\
\hline 2047694-67.2019.8.26.0000 & Não & Não & Não & Não & Não & Não & Não & Não & Não & Não \\
\hline 2049358-36.2019.8.26.0000 & Não & Não & Não & Sim & Não & Não & Sim & Não & Não & Não \\
\hline 2051214-35.2019.8.26.0000 & Não & Não & Não & Não & Não & Não & Não & Não & Não & Não \\
\hline 2053017-53.2019.8.26.0000 & Sim & Sim & Não & Sim & Sim & Não & Não & Não & Não & Não \\
\hline 2053672-25.2019.8.26.0000 & Sim & Não & Não & Sim & Sim & Não & Não & Não & Não & Não \\
\hline 2053739-87.2019.8.26.0000 & Sim & Não & Sim & Sim & Não & Não & Não & Sim & Não & Não \\
\hline 2054944-54.2019.8.26.0000 & Não & Sim & Não & Sim & Sim & Não & Não & Não & Não & Não \\
\hline 2057030-95.2019.8.26.0000 & Sim & Não & Sim & Não & Sim & Não & Não & Não & Não & Não \\
\hline 2060589-60.2019.8.26.0000 & Não & Não & Não & Não & Não & Não & Não & Não & Não & Não \\
\hline 2062370-20.2019.8.26.0000 & Não & Sim & Não & Sim & Sim & Não & Não & Não & Não & Não \\
\hline 2068735-90.2019.8.26.0000 & Sim & Sim & Sim & Sim & Não & Não & Não & Sim & Não & Não \\
\hline 2070292-15.2019.8.26.0000 & Não & Não & Não & Não & Não & Não & Não & Não & Não & Não \\
\hline 2071483-95.2019.8.26.0000 & Não & Não & Não & Não & Sim & Não & Sim & Não & Não & Não \\
\hline 2071709-03.2019.8.26.0000 & Não & Não & Não & Não & Não & Não & Não & Não & Não & Não \\
\hline 2072883-47.2019.8.26.0000 & Não & Não & Não & Não & Não & Não & Não & Não & Não & Não \\
\hline 2075351-81.2019.8.26.0000 & Sim & Sim & Não & Não & Sim & Não & Sim & Não & Não & Não \\
\hline 2075552-73.2019.8.26.0000 & Não & Não & Não & Não & Não & Não & Não & Não & Não & Não \\
\hline 2082145-21.2019.8.26.0000 & Sim & Não & Sim & Sim & Sim & Não & Não & Não & Não & Não \\
\hline 2082164-27.2019.8.26.0000 & Sim & Não & Não & Sim & Sim & Não & Sim & Não & Não & Não \\
\hline 2082569-63.2019.8.26.0000 & Sim & Não & Não & Sim & Sim & Não & Não & Não & Não & Não \\
\hline
\end{tabular}

537 GAJARDONI, Fernando da Fonseca; PEREIRA, Augusto Martins. Medidas atípicas na execução civil: análise de casos no âmbito do TJSP. In: MARCATO, Ana Cândida Menezes et al. Reflexões sobre o código de processo civil de 2015. São Paulo: Verbatim, 2018.

538 MEDEIROS NETO, Elias Marque de; REINAS, Caroline Pastri Pinto. A aplicação das medidas executivas atípicas do artigo 139, inciso IV, do CPC/2015 pelo Tribunal de Justiça do Estado de São Paulo. Revista de Processo, São Paulo, v. 286, p. 277-297, dez. 2018. Disponível em: <https://www.revistadostribunais.com.br/maf/app/resultList/document?\&docguid=Ic2b6c570e24c11 e886f0010000000000 >. Acesso em: 05 out. 2019. n.p. 


\begin{tabular}{|c|c|c|c|c|c|c|c|c|c|c|}
\hline Recurso & Art. 80 & Ir e Vir & Onerosidade & Inocuidade & Patrimonialidade & Subsidiariedade & Punição & Ocultação & Contraditório & Fundamentação \\
\hline 2083263-32.2019.8.26.0000 & Sim & Não & Não & Não & Sim & Não & Sim & Não & Não & Não \\
\hline 2084471-51.2019.8.26.0000 & Não & Não & Não & Sim & Não & Não & Sim & Não & Não & Não \\
\hline 2084933-08.2019.8.26.0000 & Sim & Sim & Sim & Sim & Não & Não & Não & Não & Não & Não \\
\hline 2085018-91.2019.8.26.0000 & $\operatorname{sim}$ & Não & Não & Sim & Sim & Não & Não & Não & Não & Não \\
\hline 2086569-09.2019.8.26.0000 & Não & Não & Não & Sim & Sim & Sim & Sim & Não & Não & Não \\
\hline 2087169-30.2019.8.26.0000 & Não & Não & Não & Não & Não & Não & Não & Não & Não & Não \\
\hline 2090034-26.2019.8.26.0000 & $\operatorname{sim}$ & Sim & Não & Não & Sim & Não & Não & Não & Não & Não \\
\hline 2091597-55.2019.8.26.0000 & Não & Sim & Não & Não & $\operatorname{sim}$ & Não & Sim & Não & Não & Não \\
\hline 2091917-08.2019.8.26.0000 & Não & Não & Não & Não & Não & Não & Não & Não & Não & Não \\
\hline 2091941-36.2019.8.26.0000 & Sim & Sim & Não & Não & $\operatorname{sim}$ & Não & Não & Não & Não & Não \\
\hline 2093392-96.2019.8.26.0000 & Sim & Não & Sim & Não & Não & Não & Não & Não & Não & Não \\
\hline $2093760-08.2019 .8 .26 .0000$ & Sim & Não & Sim & Não & Não & Sim & Não & Não & Não & Não \\
\hline 2095225-52.2019.8.26.0000 & Não & Não & Não & $\operatorname{sim}$ & $\operatorname{sim}$ & Não & $\operatorname{sim}$ & Não & Não & Não \\
\hline 2097817-69.2019.8.26.0000 & Não & Não & Não & Não & Não & Não & Não & Não & Não & Não \\
\hline 2098379-78.2019.8.26.0000 & Não & Não & Não & Sim & Sim & Não & Não & Não & Não & Não \\
\hline 2099490-97.2019.8.26.0000 & Não & Não & Não & Não & Não & Não & Não & Não & Não & Não \\
\hline 2101643-06.2019.8.26.0000 & Sim & Não & Não & Não & Não & Não & Sim & Sim & Não & Não \\
\hline 2101726-22.2019.8.26.0000 & Sim & Sim & Sim & Sim & Não & Não & Não & Não & Não & Não \\
\hline 2103856-82.2019.8.26.0000 & Não & Não & Não & Não & Não & Não & Não & Não & Não & Não \\
\hline 2103896-64.2019.8.26.0000 & Sim & Sim & Não & Sim & Sim & Não & Não & Não & Não & Não \\
\hline 2107030-02.2019.8.26.0000 & Sim & Não & Não & $\operatorname{sim}$ & Não & Não & Sim & Não & Não & Não \\
\hline 2109234-19.2019.8.26.0000 & Não & Não & Sim & $\operatorname{sim}$ & $\operatorname{Sim}$ & $\operatorname{sim}$ & $\operatorname{Sim}$ & Não & Não & Não \\
\hline 2111953-71.2019.8.26.0000 & Não & Não & Não & Não & Não & Não & Não & Não & Não & Não \\
\hline 2112423-05.2019.8.26.0000 & $\operatorname{sim}$ & Não & Não & Não & Sim & Não & Não & Não & Não & Não \\
\hline 2112676-90.2019.8.26.0000 & Sim & Não & Não & Sim & Não & Não & Sim & Sim & Não & Não \\
\hline $2113645-08.2019 .8 .26 .0000$ & Sim & Não & Não & Sim & Não & Não & Sim & Não & Não & Não \\
\hline 2114275-64.2019.8.26.0000 & Sim & Não & Não & Sim & Não & Não & Não & Não & Não & Não \\
\hline 2114302-47.2019.8.26.0000 & Não & Sim & Não & Sim & Não & Não & Não & Não & Não & Não \\
\hline 2114659-27.2019.8.26.0000 & Não & Não & Não & Não & Não & Não & Não & Não & Não & Não \\
\hline $2116374-07.2019 .8 .26 .0000$ & Sim & Não & Sim & Não & Não & Sim & $\operatorname{sim}$ & Sim & Não & Não \\
\hline 2116685-95.2019.8.26.0000 & Sim & Não & Não & Sim & Não & Não & Sim & Não & Não & Não \\
\hline $2116820-10.2019 .8 .26 .0000$ & Sim & Não & Não & Sim & Sim & Não & Não & Não & Não & Não \\
\hline 2117044-45.2019.8.26.0000 & Sim & Sim & Não & Não & Sim & Não & Não & Não & Não & Não \\
\hline 2118032-66.2019.8.26.0000 & Não & Não & Não & Não & Não & Não & Não & Não & Não & Não \\
\hline 2118071-63.2019.8.26.0000 & Sim & Sim & Sim & Sim & Não & Não & Sim & Sim & Não & Não \\
\hline 2118471-77.2019.8.26.0000 & Sim & Não & Sim & Sim & Não & Não & Não & Não & Não & Não \\
\hline 2119006-06.2019.8.26.0000 & Sim & Não & Não & Sim & Sim & Não & Sim & Não & Não & Não \\
\hline 2119815-93.2019.8.26.0000 & Sim & Sim & Não & Não & Sim & Não & Não & Sim & Não & Não \\
\hline $2120340-75.2019 .8 .26 .0000$ & Não & Não & Não & Não & Não & Não & Não & Não & Não & Não \\
\hline 2120812-76.2019.8.26.0000 & Sim & Não & Sim & Sim & Não & Não & Sim & Sim & Não & Não \\
\hline $2121476-10.2019 .8 .26 .0000$ & Sim & Não & Sim & Não & Sim & Não & Não & Não & Não & Não \\
\hline 2121579-17.2019.8.26.0000 & Sim & Sim & Sim & Sim & Não & Não & Não & Sim & Não & Não \\
\hline 2121972-39.2019.8.26.0000 & Não & Sim & Não & Não & Não & Não & Não & Não & Não & Não \\
\hline 2122179-38.2019.8.26.0000 & Não & Não & Não & Não & Não & Não & Não & Não & Sim & Não \\
\hline
\end{tabular}




\begin{tabular}{|c|c|c|c|c|c|c|c|c|c|c|}
\hline Recurso & Art. 8은 & Ir e Vir & Onerosidade & Inocuidade & Patrimonialidade & Subsidiariedade & Punição & Ocultação & Contraditório & Fundamentação \\
\hline 2122199-29.2019.8.26.0000 & Não & Não & Não & Não & Não & Não & Não & Não & Não & Não \\
\hline 2122677-37.2019.8.26.0000 & Sim & Não & Sim & Não & Não & Sim & Não & Não & Não & Não \\
\hline 2123167-59.2019.8.26.0000 & Sim & Não & Não & Sim & Sim & Não & Não & Sim & Não & Não \\
\hline 2123852-66.2019.8.26.0000 & Não & Não & Não & Não & Não & Não & Não & Não & Não & Não \\
\hline 2124021-53.2019.8.26.0000 & Sim & Sim & Não & Não & Sim & Não & Não & Não & Não & Não \\
\hline 2124034-52.2019.8.26.0000 & Sim & Sim & Sim & Não & Não & Não & Não & Não & Não & Não \\
\hline 2124138-44.2019.8.26.0000 & Sim & Sim & Não & Sim & Sim & Não & Sim & Não & Não & Não \\
\hline $2124405-16.2019 .8 .26 .0000$ & Sim & Não & Sim & Não & Sim & Não & Não & Não & Não & Não \\
\hline 2125022-73.2019.8.26.0000 & Sim & Sim & Não & Não & $\operatorname{sim}$ & Não & Não & Não & Não & Não \\
\hline $2125748-47.2019 .8 .26 .0000$ & Sim & Sim & Sim & $\operatorname{sim}$ & $\operatorname{sim}$ & Não & Não & Não & Não & Não \\
\hline 2125795-21.2019.8.26.0000 & Não & Não & Não & Sim & Não & Não & Não & Não & Não & Não \\
\hline 2125950-24.2019.8.26.0000 & Sim & Não & Sim & Não & $\operatorname{sim}$ & Não & Não & Não & Não & Não \\
\hline 2126098-35.2019.8.26.0000 & Não & Não & Não & $\operatorname{sim}$ & Não & Não & Não & Não & Não & Não \\
\hline 2126135-62.2019.8.26.0000 & Sim & Sim & Não & Sim & Não & Não & Sim & Não & Não & Não \\
\hline 2126286-28.2019.8.26.0000 & Sim & Não & Não & Sim & Sim & Sim & Não & Sim & Não & Não \\
\hline $2126435-24.2019 .8 .26 .0000$ & Sim & Sim & Não & Não & Sim & Não & Não & Não & Não & Não \\
\hline 2126484-65.2019.8.26.0000 & Sim & Não & Não & Não & Sim & Não & Não & Não & Não & Não \\
\hline 2127430-37.2019.8.26.0000 & Não & Não & Não & Não & Sim & Sim & Não & Não & Não & Não \\
\hline 2128509-51.2019.8.26.0000 & Sim & Sim & Não & Não & Sim & Não & Não & Não & Não & Não \\
\hline 2129640-61.2019.8.26.0000 & Sim & Não & Sim & Sim & Sim & Não & Não & Não & Não & Não \\
\hline 2129719-40.2019.8.26.0000 & Não & Não & Não & Não & Não & Não & Não & Não & Não & Não \\
\hline 2129894-34.2019.8.26.0000 & Não & Não & Não & Não & Não & Não & Não & Não & Não & Não \\
\hline 2130599-32.2019.8.26.0000 & Sim & Não & Não & Não & Sim & Não & Não & Não & Não & Não \\
\hline 2131338-05.2019.8.26.0000 & Sim & Não & Não & Sim & Não & Não & Sim & Não & Não & Não \\
\hline $2131362-33.2019 .8 .26 .0000$ & Sim & Não & Não & Não & Não & Não & Não & Não & Não & Não \\
\hline 2131942-63.2019.8.26.0000 & Sim & Não & Não & Não & Sim & Não & Sim & Não & Não & Não \\
\hline 2133674-79.2019.8.26.0000 & Sim & Não & Sim & Sim & Não & Não & Não & Não & Não & Não \\
\hline 2135712-64.2019.8.26.0000 & Sim & Não & Não & Sim & Não & Não & Sim & Não & Não & Não \\
\hline 2136151-75.2019.8.26.0000 & Sim & Sim & Não & Não & Sim & Não & Não & Não & Não & Não \\
\hline 2136505-03.2019.8.26.0000 & Sim & Não & Sim & Sim & Sim & Não & Sim & Não & Não & Não \\
\hline 2138305-66.2019.8.26.0000 & Sim & Não & Sim & Não & Sim & Sim & Não & Não & Não & Não \\
\hline 2138307-36.2019.8.26.0000 & Sim & Não & Não & Sim & Não & Não & Sim & Sim & Não & Sim \\
\hline 2138552-47.2019.8.26.0000 & Sim & Não & Não & Sim & Não & Não & Não & Não & Não & Não \\
\hline 2139429-84.2019.8.26.0000 & Sim & Não & Não & Sim & Não & Não & Não & Não & Não & Não \\
\hline 2140281-11.2019.8.26.0000 & Sim & Sim & Sim & Sim & Sim & Não & Sim & Não & Não & Não \\
\hline 2140402-39.2019.8.26.0000 & Sim & Não & Sim & Sim & Sim & Não & Sim & Não & Não & Não \\
\hline $2140515-90.2019 .8 .26 .0000$ & Sim & Não & Não & Não & Sim & Não & Não & Não & Não & Não \\
\hline 2140898-68.2019.8.26.0000 & Sim & Não & Sim & Não & $\operatorname{Sim}$ & Não & Não & Sim & Não & Não \\
\hline 2142673-21.2019.8.26.0000 & Sim & Sim & Não & Sim & Sim & Não & Não & Não & Não & Não \\
\hline 2142975-50.2019.8.26.0000 & Sim & Não & Não & Não & Não & Não & Não & Não & Não & Não \\
\hline $2143846-80.2019 .8 .26 .0000$ & Sim & Sim & Não & $\operatorname{sim}$ & $\operatorname{Sim}$ & Não & Não & Não & Não & Não \\
\hline 2147629-80.2019.8.26.0000 & Sim & Sim & Sim & Sim & Não & Não & Não & Não & Não & Não \\
\hline 2148404-95.2019.8.26.0000 & Não & Não & Não & Sim & Não & Não & Não & Sim & Não & Não \\
\hline 2148638-77.2019.8.26.0000 & Sim & Não & Sim & Sim & Não & Não & Não & $\operatorname{Sim}$ & Não & Não \\
\hline
\end{tabular}




\begin{tabular}{|c|c|c|c|c|c|c|c|c|c|c|}
\hline Recurso & Art. 8ㅇ & Ir e Vir & Onerosidade & Inocuidade & Patrimonialidade & Subsidiariedade & Punição & Ocultação & Contraditório & Fundamentação \\
\hline 2148908-04.2019.8.26.0000 & Sim & Não & Não & Sim & Não & Não & Sim & Não & Não & Não \\
\hline 2150272-11.2019.8.26.0000 & Não & Não & Não & Não & Não & Não & Não & Não & Não & Não \\
\hline 2150454-94.2019.8.26.0000 & Não & Não & Não & Não & Não & Não & Não & Não & Não & Não \\
\hline 2152132-47.2019.8.26.0000 & Sim & Não & Sim & Sim & Não & Não & Não & Sim & Não & Não \\
\hline 2152635-68.2019.8.26.0000 & Não & Não & Não & Não & Não & Não & Não & Não & Não & Não \\
\hline 2153609-08.2019.8.26.0000 & Sim & Não & Sim & Não & Sim & Não & Não & Não & Não & Não \\
\hline 2154141-79.2019.8.26.0000 & Não & Não & Não & Sim & Sim & Não & Sim & Não & Não & Não \\
\hline 2154152-11.2019.8.26.0000 & Não & Não & Não & Sim & Não & Não & Sim & Sim & Não & Sim \\
\hline 2155889-49.2019.8.26.0000 & Sim & Não & Não & Sim & Sim & Não & Não & Não & Não & Não \\
\hline 2156407-39.2019.8.26.0000 & Sim & Não & Sim & Sim & $\operatorname{sim}$ & Não & $\operatorname{Sim}$ & Não & Não & Não \\
\hline 2157409-44.2019.8.26.0000 & Não & Não & Não & Sim & Sim & Não & Sim & Não & Não & Não \\
\hline 2157460-55.2019.8.26.0000 & Sim & Não & Sim & Sim & Sim & Não & Sim & Não & Não & Não \\
\hline 2157734-19.2019.8.26.0000 & Sim & Não & Sim & Não & Sim & Não & Não & Não & Não & Não \\
\hline 2158708-56.2019.8.26.0000 & Não & Não & Não & Não & Não & Não & Não & Sim & Não & Não \\
\hline 2164534-63.2019.8.26.0000 & Não & Não & Não & Não & $\operatorname{sim}$ & Não & Não & Não & Não & Não \\
\hline 2166719-74.2019.8.26.0000 & Sim & Sim & Não & Sim & Não & Sim & Não & Não & Não & Não \\
\hline 2167088-68.2019.8.26.0000 & Sim & Não & Sim & Sim & Não & Não & Não & Não & Não & Não \\
\hline 2167229-87.2019.8.26.0000 & Sim & Não & Não & Sim & Sim & Não & Não & Não & Não & Não \\
\hline $2169254-73.2019 .8 .26 .0000$ & Sim & Não & $\operatorname{sim}$ & Não & Sim & Não & Não & Sim & Não & Não \\
\hline 2169337-89.2019.8.26.0000 & Não & Não & Não & Não & Não & Não & Não & Não & Não & Não \\
\hline 2176161-64.2019.8.26.0000 & Sim & Não & Não & Não & Não & Sim & Não & Sim & Não & Não \\
\hline $2177530-30.2018 .8 .26 .0000$ & Sim & Não & Não & Sim & Sim & Não & Não & Não & Não & Não \\
\hline 2178308-63.2019.8.26.0000 & Sim & Não & Não & Não & Não & Não & Não & Não & Não & Não \\
\hline 2182920-44.2019.8.26.0000 & Sim & Não & Não & Sim & Não & Não & Não & Sim & Não & Não \\
\hline 2199332-84.2018.8.26.0000 & Não & Não & Não & Sim & Sim & Não & Não & Não & Não & Não \\
\hline 2223217-30.2018.8.26.0000 & Sim & Não & Não & Sim & Não & Não & Sim & Não & Não & Não \\
\hline 2233578-09.2018.8.26.0000 & Sim & Sim & Não & Não & Não & Sim & Não & Não & Não & Não \\
\hline 2238929-60.2018.8.26.0000 & Sim & Sim & Não & Sim & Não & Não & Não & Não & Não & Não \\
\hline 2247367-75.2018.8.26.0000 & Sim & Sim & Não & Sim & Sim & Não & Sim & Sim & Sim & Não \\
\hline 2248190-49.2018.8.26.0000 & Sim & Não & Sim & Não & Sim & Não & Não & Não & Não & Não \\
\hline 2250396-36.2018.8.26.0000 & Sim & Não & Não & Sim & Sim & Não & Não & Não & Não & Não \\
\hline 2257231-40.2018.8.26.0000 & Sim & Não & Não & Sim & Não & Sim & Sim & Não & Sim & Sim \\
\hline $2261837-14.2018 .8 .26 .0000$ & Não & Não & Não & Sim & Sim & Não & $\operatorname{Sim}$ & Não & Não & Não \\
\hline 2266747-84.2018.8.26.0000 & Sim & Sim & Não & Não & Sim & Não & Não & Não & Não & Não \\
\hline $2269880-37.2018 .8 .26 .0000$ & Sim & Não & Não & Sim & Sim & Não & Não & Não & Não & Não \\
\hline 2275384-24.2018.8.26.0000 & Sim & Não & Não & Sim & Não & Não & Sim & Não & Não & Não \\
\hline
\end{tabular}

